\title{
A review of the lower and middle Miocene of northern Belgium
}

\author{
Stephen LOUWYE ${ }^{*}$, Jef DECKERS ${ }^{2}$, Jasper VERHAEGEN ${ }^{3}$, Rieko ADRIAENS ${ }^{4}$ \& Noël VANDENBERGHE 5
}

\author{
${ }^{1}$ Paleontology and Paleoenvironment, Department of geology, Ghent University, Krijgslaan 281/S8; Ghent, Belgium; stephen.louwye@ \\ ugent.be. \\ ${ }^{2}$ VITO, Flemish Institute for Technological Research, Boeretang, Mol, Belgium. \\ ${ }^{3}$ VPO, Planning Bureau for the Environment and Spatial Development, Department of Environment, Flemish Government, Koning \\ Albert II-laan 20, 1000 Brussels, Belgium. \\ ${ }^{4}$ Qmineral Analysis \& Consulting, Heverlee-Leuven, Belgium. \\ ${ }^{5}$ Dept. Earth and Environmental Sciences, KU Leuven, Belgium. \\ * corresponding author.
}

\begin{abstract}
The stratigraphy, sedimentology and paleogeography of the lower and middle Miocene Berchem and Bolderberg Formations from northern Belgium have been extensively studied during the last decades, a.o. in the framework of doctoral research, as parts of subsurface mapping and interregional geological correlation initiatives by governmental organizations. The last formal stratigraphical revision on formation level, however, almost dates from two decades ago, notwithstanding the fact that a wealth of new data has become available. A compilation and assessment of the stratigraphical data of the lower and middle Miocene has been carried out and a refined stratigraphical framework - based on dinoflagellate cyst stratigraphy - is presented. Recommendations for the National Commission for Stratigraphy of Belgium are proposed. A new member, the Molenbeersel member, is proposed for the glauconite-bearing silts and fine sands in the upper part of the Bolderberg Formation in the Roer Valley Graben.Rhine during the late Tortonian.
\end{abstract}

KEYWORDS: Neogene, stratigraphic review, dinoflagellate cyst biostratigraphy, Molenbeersel member, southern North Sea Basin.

\section{Introduction}

The North Sea was a semi-enclosed basin during the Neogene. The marine connection between the southern North Sea Basin and the Channel was prevented by the Weald-Artois ridge, while in the north an open marine connection with the NorwegianGreenland Sea existed (Ziegler, 1990; Rasmussen et al., 2008; Rasmussen et al., 2010).

Tectonic uplift of northern Belgium during late Oligocene time pushed the southern coastline of the North Sea northwards, and late Oligocene sedimentation in Belgium was limited to a thin cover of glauconitic sand in northern Belgium; it is only well developed in the subsiding Roer Valley Graben (RVG) in the very northeast (Dusar et al., 2020, this volume). At the beginning of the Miocene, during the global sea-level rise after the Mi1 glacial maximum (Miller et al., 1991), sea levels rose and northern Belgium was invaded by a marine transgression from a northern to northwestern direction (Louwye, 2005). Furthermore, Munsterman \& Deckers (2020, this volume) recorded in two wells in the northeastern part of the Campine latest Oligocene earliest Miocene (Aquitanian - early Burdigalian) deposits and proposed a transgressive phase from the Roer Valley Graben towards the Campine area.

The marine and continental lower and middle Miocene deposits are restricted to northern Belgium and crop out in the vicinity of the city of Antwerp (Fig. 1). In the Campine area, east of Antwerp, lower and middle Miocene sediments are present in the subsurface and are covered by the late Miocene deposits of the Diest Formation (Houthuys et al., 2020, this volume). The Miocene deposits rest unconformably on Oligocene or older sediments, and the hiatus between the Oligocene and Miocene is related to the previously mentioned tectonic uplift during the late Oligocene (Vandenberghe et al., 1998). The sea invaded northern Belgium during the early Miocene from a north-northwestern direction (Antwerp Campine area) and transgressed fairly rapidly during Burdigalian - Serravallian time to the eastern Campine area. The deposition in the eastern part of the Campine area was controlled by the subsidence of the Roer Valley Graben and resulted in considerable thicknesses $(>200 \mathrm{~m}$; Munsterman et al., 2019).

The lower and middle Miocene sediments are essentially fine-grained to coarse-grained sand, with a varying, but always considerable content of glauconite. Parts of the lower and middle Miocene are decalcified, yet calcareous (micro)fossils and macrofossils are locally abundantly present. The depositional architecture, sedimentology and fossil assemblages all indicate that sedimentation took place in a shallow marine environment.
The lower and middle Miocene deposits are formally grouped in the Berchem Formation and the Bolderberg Formation (De Meuter \& Laga, 1976; see also Laga et al., 2001) (Table 1). The former formation was deposited in northernmost Belgium, between Antwerp in the west to Lommel in the east, while the latter formation was deposited further southeast (Fig. 1). Correlation between the Berchem and the Bolderberg Formations has always been hampered by the occurrence of the late Miocene Diest Formation, deposited in a large incised valley in between the two aforementioaned formations. The Berchem Formation holds the Edegem Member, the Kiel Member, the Antwerpen Member and the Zonderschot Member, while the Bolderberg Formation is divided into the Houthalen Member and the Genk Member, including the white quartz sand Opgrimbie facies (see 2.3.3.) (Table 1). The complete thickness of the Berchem Formation increases from about $30 \mathrm{~m}$ in the west to over $100 \mathrm{~m}$ in the east. The Bolderberg Formation has a maximum thickness of circa $160 \mathrm{~m}$ in the Roer Valley Graben in northeast Belgium (Molenbeersel borehole (BGD 049w0225, DOV kb18d49w-B225) according to Broothaers et al. (2012), truncates locally the subjacent formations and wedges out in a westward direction.

The most recent formal revision of the lithostratigraphy of the lower and middle Miocene of Belgium already dates from four decades ago (De Meuter \& Laga, 1976), and was only revised by the Stratigraphical Commission of Belgium in the beginning of this century (Laga et al., 2001). However, many recently published studies discuss facets of biostratigraphy, sedimentology, lithostratigraphy, etc. of the lower and middle Miocene (see below) and are complemented by initiatives of governmental authorities to construct detailed, comprehensive geological models. The rationale of this paper is to synthesize the available lithostratigraphical and biostratigraphical data, to review the newly available data, to evaluate the validity and status of formations and members, and to present a consistent stratigraphic framework. An overview of the discussed outcrops and boreholes can be found at https://www.dov.vlaanderen.be/ data/opdracht/2020-022192.

\section{Stratigraphy}

\subsection{Berchem Formation in the type area}

2.1.1. The formation, sedimentology and wireline log signature

The Berchem Formation was for the first time formally defined by De Meuter \& Laga (1976) as a green to blackish, fine to medium-grained sand, often very glauconitic and with a 


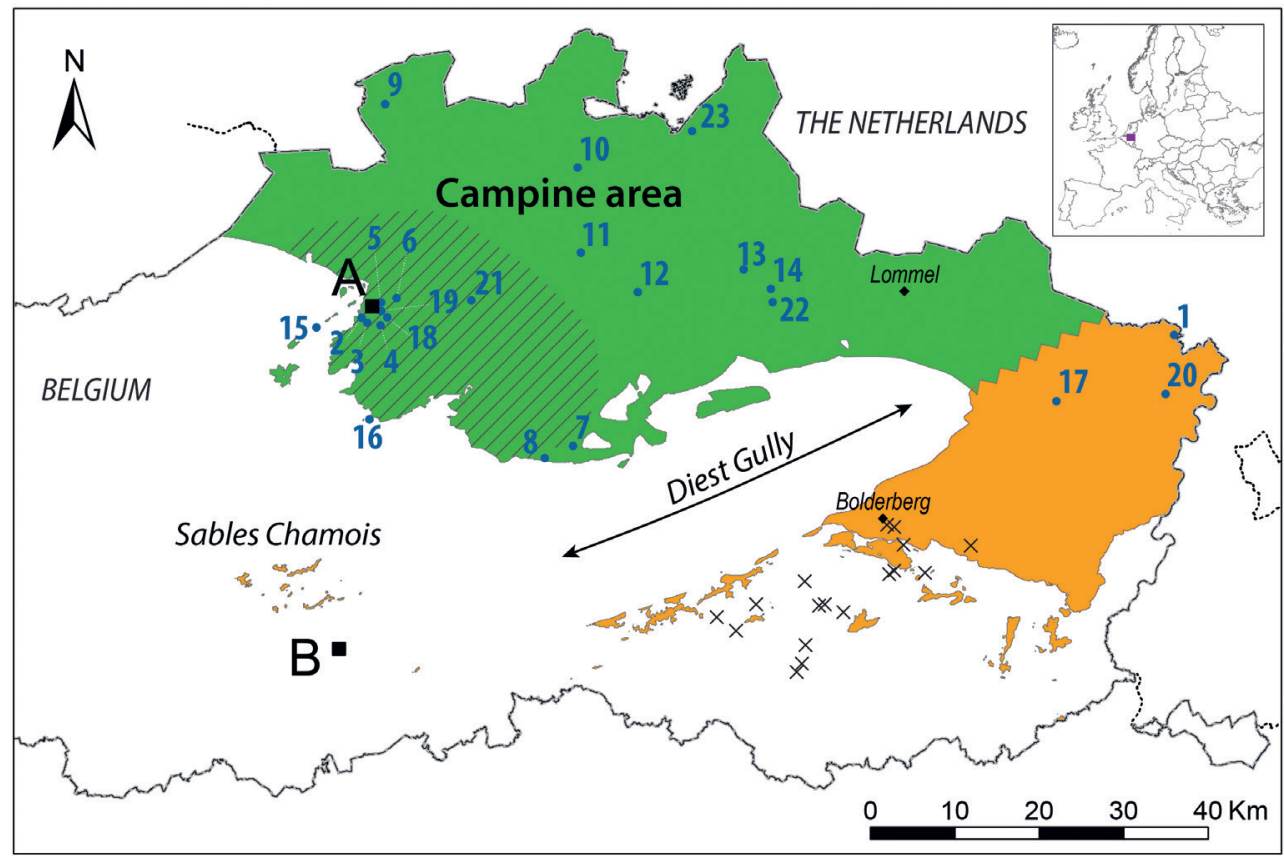

Berchem Formation

Edegem Member

Bolderberg Formation

$\times$ Sites with Miocene sandstone boulders

- Boreholes and outcrops

\begin{tabular}{|c|c|c|c|c|c|c|c|}
\hline Name & Code BGD & Code DOV & $\mathrm{Nr}$ & Name & Code BGD & Code DOV & $\mathrm{Nr}$ \\
\hline Molenbeersel & 049W0225 & $\mathrm{kb} 18 \mathrm{~d} 49 \mathrm{w}-\mathrm{B} 225$ & 1 & Retie & 031W0243 & kb17d31w-B228 & 13 \\
\hline Antwerp - Montignystraat & 028W0394 & $\mathrm{kb} 15 \mathrm{~d} 28 \mathrm{w}-\mathrm{B} 448$ & 2 & Mol & 031W0221 & $\mathrm{kb} 17 \mathrm{~d} 31 \mathrm{w}-\mathrm{B} 212$ & 14 \\
\hline Antwerp - Van Rijwijcklaan & 028W0395 & $\mathrm{kb} 15 \mathrm{~d} 28 \mathrm{w}-\mathrm{B} 449$ & 3 & Burcht outcrop & & TO-20050101A & 15 \\
\hline Berchem - Grote Steenweg & 028W0397 & $\mathrm{kb} 15 \mathrm{~d} 28 \mathrm{w}-\mathrm{B} 451$ & 4 & Terhagen outcrop & & TO-20050101B & 16 \\
\hline Antwerp - Kievitstraat outcrop & 028W0399 & $\mathrm{kb} 15 \mathrm{~d} 28 \mathrm{w}-\mathrm{B} 453$ & 5 & Wijshagen & 048W0180 & $\mathrm{kb} 18 \mathrm{~d} 48 \mathrm{w}-\mathrm{B} 181$ & 17 \\
\hline Borgerhout - Rivierenhof & $028 \mathrm{E} 0499$ & $\mathrm{~kb} 15 \mathrm{~d} 28 \mathrm{e}-\mathrm{B} 580$ & 6 & Berchem & & TO-20150701 & 18 \\
\hline Zonderschoot & & TO-19720101 & 7 & Antwerp & & TO-20190417 & 19 \\
\hline Heist-op-den-Berg & & kb24d59e-B180 & 8 & Maaseik & 049W0220 & $\mathrm{kb} 18 \mathrm{~d} 49 \mathrm{w}-\mathrm{B} 220$ & 20 \\
\hline $\begin{array}{l}\text { Kalmthout } \\
\text { Sors }\end{array}$ & 006Е 0110 & kb7d6e-B239 & 9 & Oelegem & 029W0378 & $\mathrm{kb} 16 \mathrm{~d} 29 \mathrm{w}-\mathrm{B} 401$ & 21 \\
\hline Rijkevorsel & $016 \mathrm{E} 0153$ & kb8d16e-B36 & 10 & Mol & 031W0314 & ON-Mol-1 & 22 \\
\hline Oostmalle & $029 \mathrm{E} 0249$ & kb16d29e-B276 & 11 & Weelde & $008 \mathrm{E} 0159$ & kb8d8e-B161 & 23 \\
\hline Poederlee & 030W0300 & kb16d30w-B315 & 12 & & & & \\
\hline
\end{tabular}

Figure 1. Location of the study area with studied boreholes and outcrops (with DOV-archive numbers), distribution of the Berchem Formation, Edegem Member and Bolderberg Formation, and occurrence of Miocene sandstone boulders. A: Antwerp, B: Brussel.

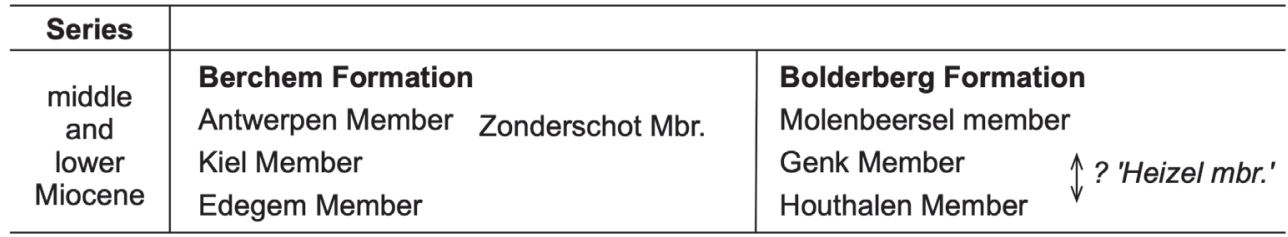

Table 1. Lithostratigraphy of the Berchem Formation and Bolderberg Formation in northern Belgium. minor clay content. Shells are abundantly present, dispersed or concentrated in massive layers. Parts of the formation, such as the Kiel Member, are locally decalcified. A distinct gravel bed of dark, rounded flint pebbles is present at the base. The type locality is Berchem (De Meuter \& Laga, 1976) and the type sections of the members were temporary outcrops for the highway around the city of Antwerp (see Fig. 2 for details).

For decades, the Edegem Member, the Zonderschot Member and the Antwerpen Member of the Berchem Formation have been extensively searched for macrofossils, especially mollusks (a.o., Glibert, 1945, 1952, 1954; Herman \& Marquet, 2007). Recently macrofossils have been retrieved and studied from the Kiel Member (Everaert et al., 2019; De Schutter \& Everaert, 2020, this volume). The Berchem Formation proved to hold a rich fossil fauna of marine mammals which occur in specific horizons (Misonne, 1958; Lambert, 2005, 2007, 2008; Lambert \& Louwye, 2006; Louwye et al., 2010; Steeman, 2010; Dewaele et al., 2017a, 2017b). The first biostratigraphical studies of the Berchem Formation were carried out with calcareous microfossils (mainly foraminifers) retrieved from temporary outcrops made for large infrastructure works around the city of Antwerp (a.o., Hooyberghs \& De Meuter, 1972; De Meuter, 1980; Hooyberghs, 1980, 1983). A biostratigraphical analysis with organic-walled dinoflagellate cysts of the members of the Berchem Formation in the type locality was carried out by Louwye et al. (2000). The latter authors analyzed samples from five temporary outcrops which were described in detail by De Meuter et al. (1976), and they correlated the deposits with the Miocene dinoflagellate cyst biozonation by de Verteuil \& Norris (1996), defined in the US Atlantic Coastal Plain. The results by Louwye et al. (2000) can now be re-evaluated following the comprehensive and $\mathrm{Sr}$ calibrated biozonation defined onshore and offhore Denmark (Dybkjær \& Piasecki, 2010; Eidvin et al., 2014) (Fig. 3).

Based on data from Verhaegen (2020, this volume), the modal grain size of the Berchem Formation varies between 130 and $330 \mu \mathrm{m}$, with an average of $220 \pm 56 \mu \mathrm{m}$. The Kiel Member and Antwerpen Member are generally slightly coarser than the Edegem Member. The modal grain size of the Edegem Member, 


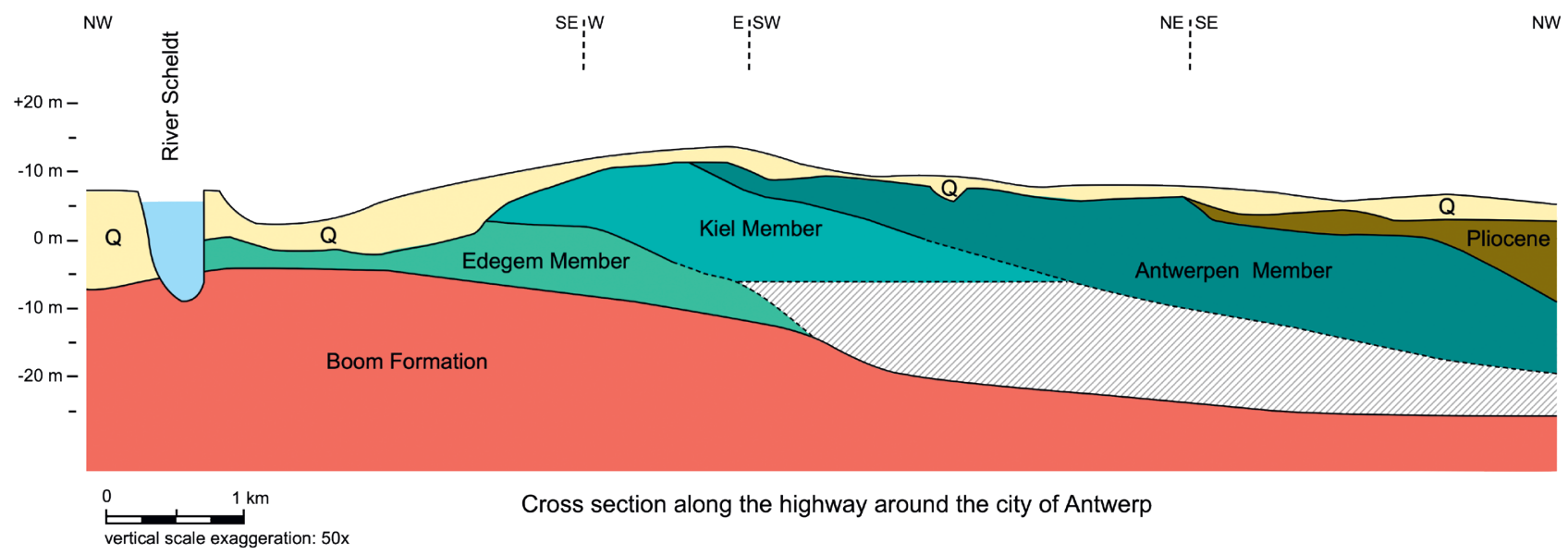

Figure 2. Geological cross section of the Berchem Formation, including the Edegem, Kiel and Antwerpen Members, in the type area. The type area is along the highway around the city of Antwerp and was defined in the temporary outcrops Antwerp - Montignystraat, Antwerp - Van Rijswijcklaan, Berchem - Grote Steenweg, Borgerhout - Rivierenhof (for location of the temporary outcrops, see Fig. 1). Hatched area: no lithostratigraphic data available. Dashed line: location and depth of profile. After Laga (unpublished, archives BGD PGL 74-103-1bis v2).

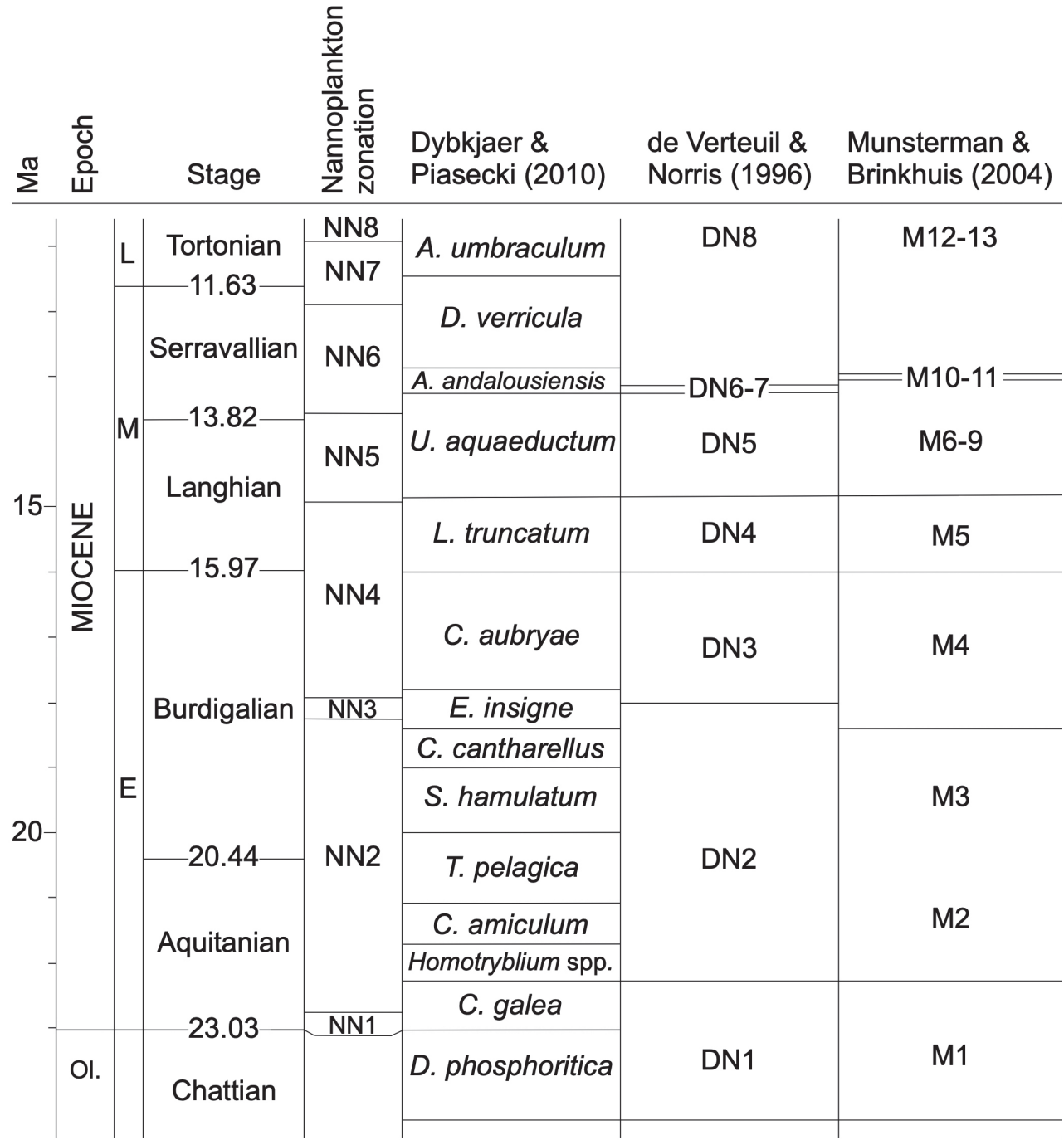




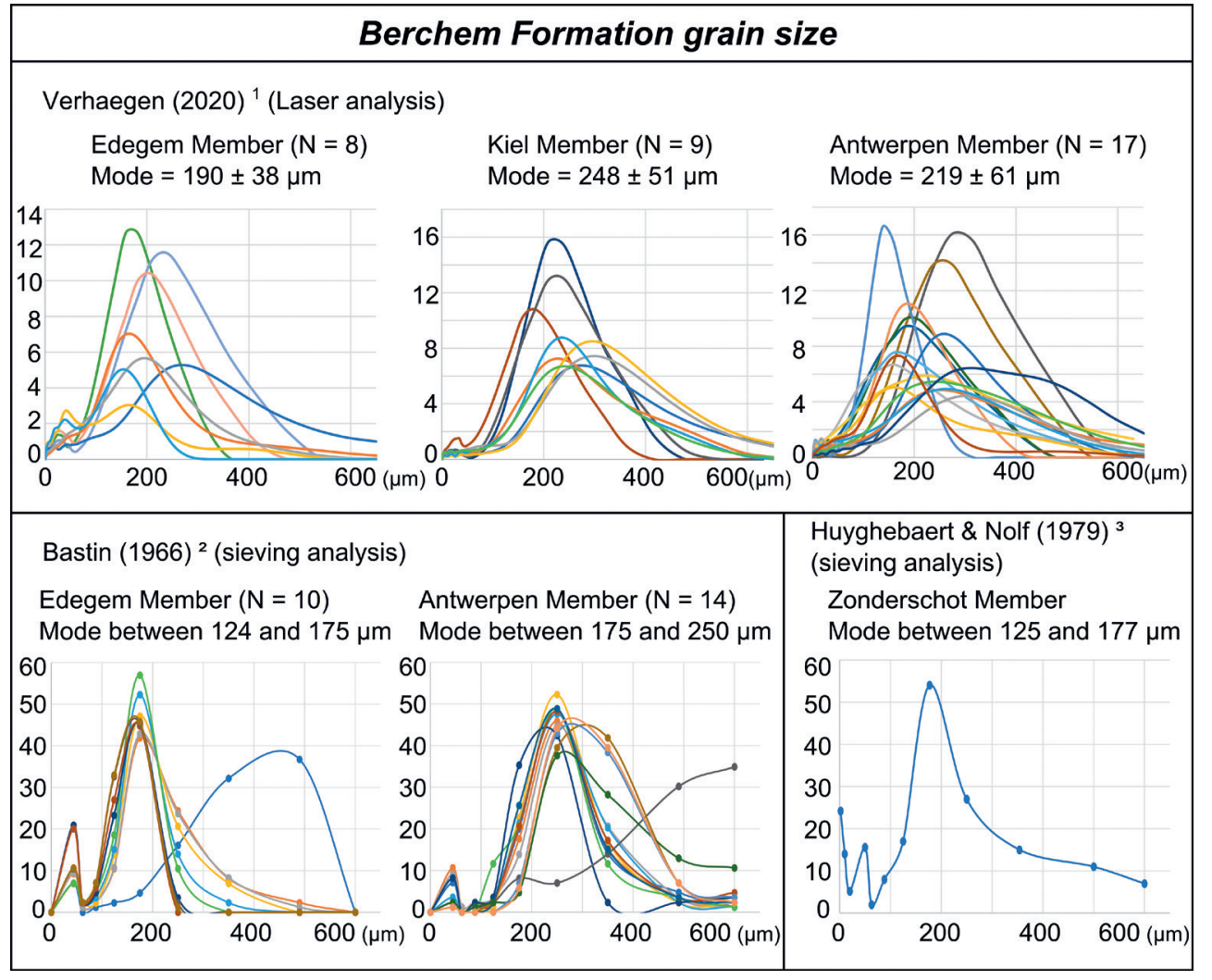

Figure 4. Grain size distribution curves for the different members of the Berchem Formation. 1 Data from Verhaegen (2020, this volume), based on laser analyses. 2 Data from Bastin (1966) based on sieving analyses. The curves based on sieving are less accurate than those based on laser analyses as less grain size intervals are defined during sieving. For Bastin (1966) the following intervals were measured: $0-44$ $-62-88-124-175-250-$ $350-490-600 \mu \mathrm{m}$. Data points are indicated on the curves. 3 Data from Huyghebaert \& Nolf (1976), also based on sieving analysis. Following intervals were measured: $0-2-10-20$ $-50-63-88-125-177-250-$ $354-500-600 \mu \mathrm{m}$. Data points are indicated on the curve. minerals). Both K-feldspar and plagioclase are present $(<15 \%)$. The carbonate content is highest in the Edegem Member (15$20 \%)$ and lowest in the Kiel Member $(<5 \%)$. Depending on the fossil species, calcite or aragonite are present. Siderite can occur as secondary mineral.

The Berchem Formation is characterized by a large amount of epidote, amphiboles and garnet, making up on average more than $50 \%$ of the transparent heavy mineral composition (Verhaegen et al., 2019; Verhaegen, 2020, this volume). The values for these mineral groups combined are the highest of any Belgian Neogene formation. The highest content (36\%) of epidote and amphibole, related to a northern marine sediment input, is reached in the Antwerpen Member (Verhaegen, 2020, this volume). The Berchem Formation is relatively rich in $\mathrm{CaO}$ and $\mathrm{Na}_{2} \mathrm{O}$ compared to the other Neogene units, which may be related to the unweathered nature of these sediments and their high smectite clay content, in comparison to other Belgian Neogene units. The Berchem Formation is also relatively rich in $\mathrm{K}_{2} \mathrm{O}, \mathrm{MgO}, \mathrm{P}_{2} \mathrm{O}_{5}$ and $\mathrm{Al}_{2} \mathrm{O}_{3}$, all components being related to the high glauconite content (Verhaegen, 2019). The elevated $\mathrm{P}_{2} \mathrm{O}_{5}$ in the bulk analysis of glauconite pellets of the Berchem Formation could be related to the common presence of phosphatic pebbles and bone fragments; in this respect it is remarkable that glauconite pellets in the Berchem Formation generally have a $\mathrm{P}_{2} \mathrm{O}_{5}$ content $>0.15 \%$ with outliers $>1 \%$ compared to values $<0.10 \%$ for Eocene and Paleocene glauconite pellets, including authigenic glauconites from the Lutetian 'bande noire' having on average $0.04 \% \mathrm{P}_{2} \mathrm{O}_{5}$ content. A higher $\mathrm{P}_{2} \mathrm{O}_{5}$ content can be observed in the overlying Neogene units as well, likely due to continued reworking of lower Miocene glauconites (Adriaens, 2015; Verhaegen, 2019).

On wireline log data, the Berchem Formation is characterized by high gamma ray (GR) and moderate resistivity values. While the gamma ray values can be similar to those of the underlying clays or sandy clays of the Boom and Eigenbilzen Formations, the resistivity values of the sand of the Berchem Formation are markedly higher. The lower boundary of the Berchem Formation therefore coincides with a strong upward increase in resistivity. Compared to the Berchem Formation, the overlying Diest Formation is characterized by lower gamma ray and higher resistivity values which agree with the smaller amounts of glauconite and an overall coarser grain size, except for the Dessel Member (Adriaens, 2015). The boundary between the Berchem
Formation and Diest Formation can therefore be positioned at an upward decrease in gamma ray values and increase in resistivity values. Generally, the highest gamma ray values are situated in the upper part of the Berchem Formation (Fig. 5).

\subsubsection{Edegem Member}

Nyst (1861) first observed the Edegem Member and described the unit as 'Sables d'Edeghem à Panopea menardii' in a quarry near Antwerp. The Edegem Member was regarded as the lower part of a twofold middle Miocene unit, named the 'Anversien' (Cogels \& Van Ertborn 1879; de Heinzelin, 1956). This view was also adopted during the International Neogene Symposium in 1961 (Tavernier \& de Heinzelin, 1963). The base of the Edegem Member is formed by the Burcht Gravel consisting of dark rounded flint pebbles, shell fragments, shark teeth and bone fragments. Reworked foraminifers, septaria and glauconite provide evidence for substantial reworking of sediment from the underlying Oligocene Boom Formation (Vandenberghe et al., 1998). The Edegem Member consists of green to grayishgreen fine-grained, clayey and glauconitic sand. Large numbers of mollusks are dispersed throughout the sediment (De Meuter \& Laga, 1976). In general, the granulometry of the Edegem Member displays an upwards coarsening signature as observed in two locations in the Antwerp area (Bastin, 1966), corroborated by the log-interpretation of the Edegem Member in borehole Oelegem (Fig. 5). Grain-size distribution curves of glauconite are similar to the quartz grain size distribution curve. This indicates that the glauconites of the Edegem Member are reworked and were transported together with the quartz grains (Adriaens, 2015). The glauconite content of the Edegem Member is smaller than in the Antwerpen Member (Adriaens, 2015), which explains the paler color of sediments of the former compared to the latter. The Edegem Member reaches its largest thickness of about $12 \mathrm{~m}$ just east of the city of Antwerp (Deckers et al., 2019).

The first biostratigraphical analysis of the Edegem Member was carried out with planktonic foraminifera by Hooyberghs \& De Meuter (1972) in unspecified temporary outcrops in the Antwerp area. The presence of a considerable number of reworked foraminifera led to an erroneous correlation with the middle Oligocene Globerigerina ampliapertura N1/P20 Zone of Blow (1969). Hooyberghs (1983) revised the assessment through a study at Terhagen where the presence of Globorotalia kugleri and Globogerinoides primordius led to a revised correlation with the 


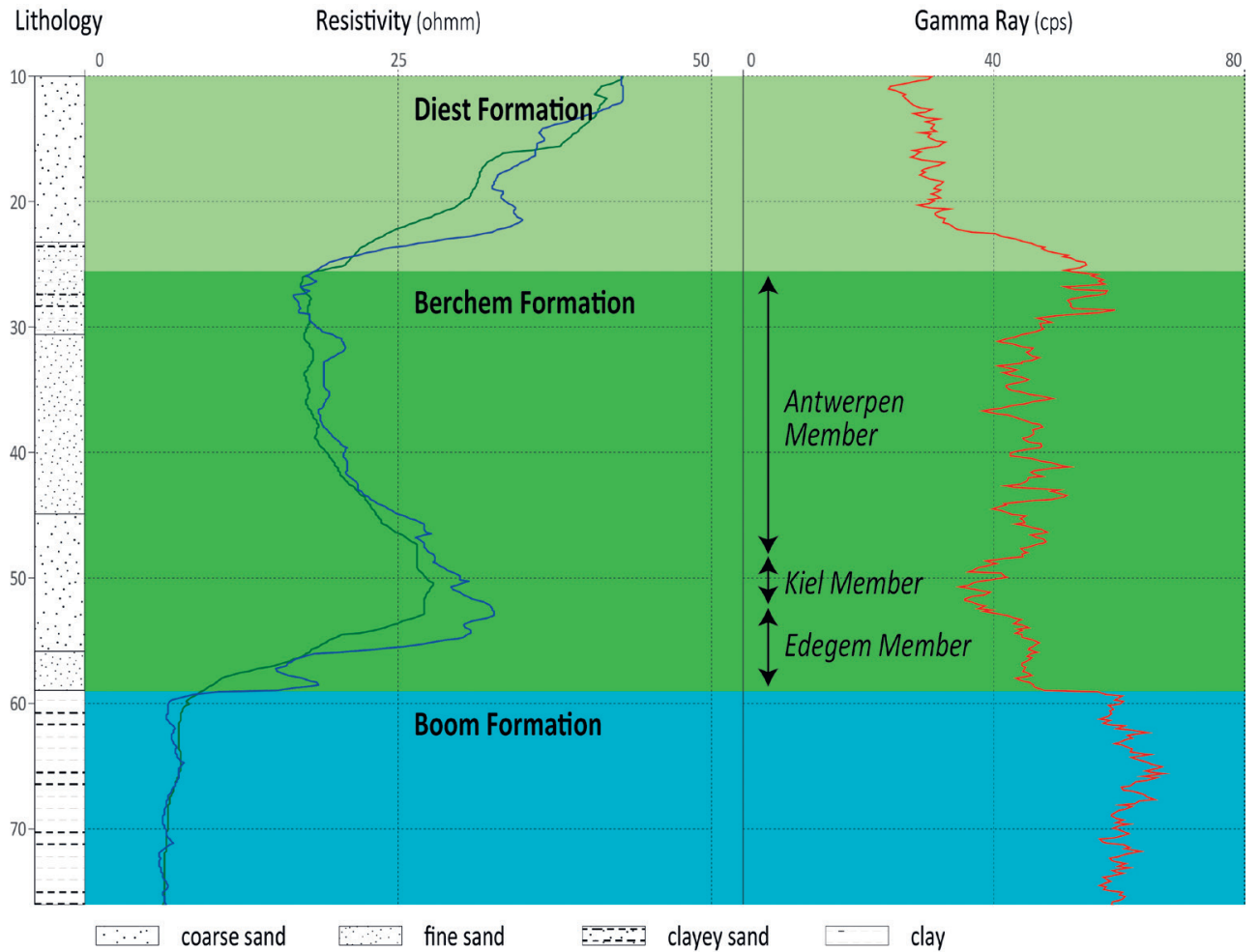

Figure 5. The characteristic log-signature of the Berchem Formation (not in the type section) in the Oelegem borehole (DOV kb16d29w-B401). The members of the Berchem Formation are tentatively interpreted. The interpretation of the Edegem Member is based on the brighter color of the sediments (from $52 \mathrm{~m}$ onwards) and the description of gray-green clayey sands (from 56-60 m depth), the Kiel Member on the indication of decalcification (between 48$52 \mathrm{~m}$ depth), and the Antwerpen Member on the dark green to black color and very glauconiterich nature of the sediments.
Aquitanian Zone N4 of Blow (1969). Hooyberghs \& Moorkens (1988) presented in a synthetic paper a correlation with the planktonic foraminifera NPF11 Globigerinoides primordius Zone defined by Spiegler et al. (1988), also indicating an Aquitanian age. The biostratigraphical analysis of the planktonic foraminifera by Hooyberghs (1996a) from a temporary outcrop at Wilrijk confirmed the Aquitanian age of the Edegem Member, although Globorotalia kugleri was not recorded. Doppert et al. (1979) placed the benthic foraminifera from the Edegem Member in the lower Miocene BFN1 Trifarina gracilis rugulosa - Elphidium ungeri Zone, an assemblage zone erected by the latter authors and based on the work by De Meuter \& Laga (1976) in a temporary outcrop in Antwerp. The compilation by Willems et al. (1988) indicates a correlation with the benthic foraminifera Zone B7, a zone of earliest Miocene age, not further specified. Calcareous nannoplankton of the Edegem Member was studied by Martini \& Müller (1973) and correlated to the mid-Burdigalian NN3 Zone of Martini (1971). According to Verbeek et al. (1988) the Edegem Member correlates to the Discoaster druggii NN2 Zone and the Sphenolithus belemnos NN3 Zone defined by Martini (1971). The correlation is indicative for an Aquitanian to Burdigalian age. Gaemers (1988) examined Gadidae otoliths and placed them in his Colliolus johanetta Zone11. Rare Bolboforma rotundata were recorded in the Edegem Member in temporary outcrops in the Antwerp area, and point to an age between $23.8 \mathrm{Ma}$ and $18 \mathrm{Ma}$ according to Spiegler (2001), i.e. latest Chattian to early Burdigalian. Janssen \& King (1988) reviewed previous pteropod collections from the Edegem Member and proposed a correlation with the early Miocene Pteropod Zone 18 based on the occurrence of Vaginella austriaca. Janssen (2001) suggested an age no older than late Burdigalian for the Edegem Member.

The Edegem Member from the temporary outcrops in Antwerp Montignystraat (BGD 028W0394, DOV kb15d28w-B448) and Van Rijswijcklaan (BGD 028W0395, DOV kb15d28w-B449) (Fig. 2, see also De Meuter et al., 1976) holds the dinoflagellate cysts Exochosphaeridium insigne species and Cordosphaeridium cantharellus, indicative of a correlation of the Edegem Member with the Cordosphaeridium cantharellus Zone (Dybkjær \& Piasecki, 2010) (Fig. 6). The new Sr-dating of dinoflagellate cyst bioevents by the latter authors allows to constrain the age of the Edegem Member between $19 \mathrm{Ma}$ and 18.4 Ma (early Burdigalian).

Glauconite grains pose particular problems for radiometric dating because of their complicated origin and slow early evolution, and therefore are called sub-authigenic by Dickin
(2005). Also, glauconite pellets can be reworked at a considerable scale as was demonstrated for the Tortonian Diest Formation in the Campine area (Vandenberghe et al., 2014). Still, many attempts using glauconites for dating strata have been undertaken with a varying success rate (Odin, 1982; Amorosi, 1997; Dickin, 2005). Radiometric glauconite dating of the Miocene deposits of northern Belgium was also attempted (Odin et al., 1969, 1974; Keppens, 1981; Keppens \& Pasteels, 1982) and the results were summarized by Odin \& Kreuzer (1988) in the IGCP 124 North Sea stratigraphy review volume (Vinken, 1988). The reliability of the obtained ages was evaluated through their compatibility with established biostratigraphical data of the strata and through the similarity of the ages obtained by the couples $\mathrm{K}-\mathrm{Ar}$ and $\mathrm{Rb}$ $\mathrm{Sr}$ in the same stratigraphic level. Applying these criteria, the glauconites in the Edegem Member indicate K-Ar ages between 21.3 Ma and 26.6 Ma (Aquitanian - Chattian) while the Rb-Sr ages between 24 and $30 \mathrm{Ma}$ (Chattian - Rupelian) are considered a result of reworking, a conclusion already reached in an earlier paper by Odin et al. (1969) for a sample from the Edegem Member at Terhagen.

\subsubsection{Kiel Member}

The Kiel Member was for the first time observed by Vanden Broeck (1874) during the construction works for the fortresses around the city of Antwerp. The latter author recognized already the relation with the subjacent Edegem Member and described the Kiel Member then as 'Partie supérieure altérée des sables à Panopées du Kiel'. The name was never really in use and the sandy Kiel unit was even not discussed during the International Neogene Symposium in 1961 (Tavernier \& de Heinzelin, 1963).

The Kiel Member was formally re-introduced by De Meuter \& Laga (1976) and described in the type locality Kiel (a suburb of the city of Antwerp) as a non-fossiliferous (i.e. decalcified), medium fine-grained to coarse-grained sand, very rich in glauconite, sometimes concentrated in patches. Thin layers of coarser sand grains are occasionally present at the base of the unit. This facies occurs in the south and central part of the city of Antwerp. To the north and east of Antwerp, however, this member becomes fossiliferous, and renders the distinction with the superjacent Antwerpen Member difficult or even impossible (De Meuter \& Laga, 1976). The validity of this facies as a separate member was questioned (Louwye et al., 2000). Everaert et al. (2020, this volume) studied several temporary outcrops of the Kiel Member in Antwerp and could distinguish the Kiel and Antwerpen Members by a slight but marked color difference due 


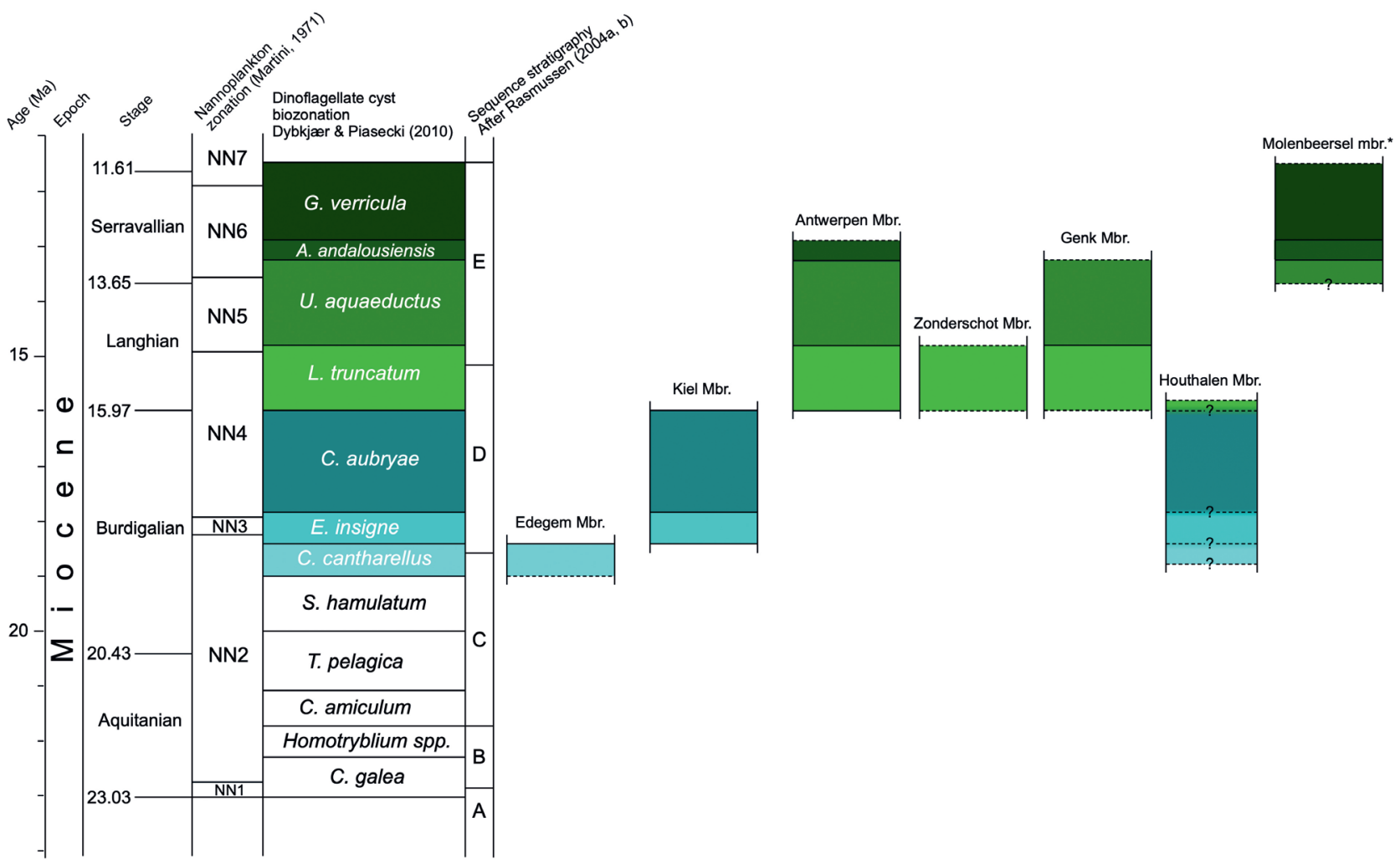

Figure 6. Stratigraphic position of the lower and middle Miocene lithostratigraphic units (members) in northern Belgium. The correlation to chronostratigraphy is based on the dinoflagellate cyst zonation of Dybkjær \& Piasecki (2010). Correlation of the standard nannoplankton zonation (Martini, 1971) with the dinoflagellate cyst zonation is after Dybkjær \& Piasecki (2010). Solid line between zones: lower or upper boundary was recognized. Dashed lines: lower or upper boundary was not recognized or unsure. ?: inferred stratigraphic range. *: stratigraphic position after Munsterman \& Deckers (2020, this volume). The position of the members versus sequence stratigraphy of Rasmussen (2004a, b) is indicated.

to a somewhat lower clay and glauconite content and a coarser sand fraction in the Kiel Sand Member.

The Kiel Member was analyzed biostratigraphically with dinoflagellate cysts by Louwye et al. (2000) in temporary outcrops around Antwerp, namely Van Rijswijcklaan and Grote Steenweg (BGD 028W0397, DOV kb15d28w-B451) (Fig. 2, see also De Meuter et al., 1976). The recovered dinoflagellate cyst assemblages had a low diversity and poor to medium preservation, contrary to the subjacent and superjacent members where diverse and well-preserved assemblages were recorded. The presence of Exochosphaeridium insigne, the marker species of the eponymous zone of Dybkjær \& Piasecki (2010), in the lower part of the Kiel Member in the Van Rijswijcklaan combined with the absence of Cordosphaeridium cantharellus, refers the lower part of Kiel Member to the (lower part of the) Exochosphaeridum insigne Zone of mid-Burdigalian age $(18.4 \mathrm{Ma}-17.8 \mathrm{Ma})$. The upper part of the Kiel Member in the Grote Steenweg outcrop belongs to the superjacent Cousteaudinium aubryae Zone defined by the first occurrence of the eponymous species to the first occurrence of Labyrinthodinium truncatum. The latter species is not recorded in the upper part of the Kiel Member. The Cousteaudinium aubryae Zone has a late Burdigalian age (17.8 Ma to $15.97 \mathrm{Ma}$ ). The Exochosphaeridum insigne Zone was also recorded by Louwye et al. (2000) in the lower part of the Kievitstraat outcrop more to the north (BGD 028W0399, DOV kb15d28w-B453) (see also De Meuter et al., 1976), and is immediately covered by the Langhian Labyrinthodinium truncatum Zone of Dybkjær \& Piasecki (2010) (see below). The Cousteaudinium aubryae Zone is thus lacking at the Kievitstraat ourcrop, and this implies a local hiatus of circa 1.8 Ma. It is worth mentioning that all sediments at this site were lithostratigraphically interpreted by De Meuter et al. (1976) as belonging to the Antwerpen Member. The Kiel Member was deposited between 18.4 Ma and 15.97 Ma (middle to late Burdigalian) (Fig. 6).

In their study of the stratigraphy and the macrofossils of three temporary outcrops of the Kiel Sand in the Antwerp area, Everaert et al. (2020, this volume) also report on the dinoflagellate cysts assemblages. The relative dating with dinoflagellate cysts, albeit following the biozonation by de Verteuil \& Norris (1996), indicate the presence of the DN2 and DN3 Zones and is in agreement with the above-mentioned zonation by Dybkjær \& Piasecki (2010) (Fig. 3). The dinoflagellate cyst analysis of a sample from the very base of the Kiel Member however pointed to a late Aquitanian age. The cause for this deviating inferred age of this sample needs further elucidation. Age dating of glauconites in the Berchem Formation shows that reworking is not uncommon even in the Antwerpen Member (see below). This recent study on the Kiel Member confirms the hiatus between the Kiel and Antwerpen Members expressed by the rapid disappearance of dinoflagellate cyst biozone DN3 in northern direction (Everaert et al., 2020, this volume, fig. 11); these authors even suggest to locate the Early Miocene Unconformity (EMU) of Munsterman et al. (2019) at this level.

As is the case for the Edegem Member, the Kiel Member contains glauconite which, based on radiometric dating and grain-size distribution curves, are presumed to be reworked (Odin et al., 1974; Vandenberghe et al., 2014; Adriaens, 2015). The radiometric datings further show divergence between $\mathrm{K}-\mathrm{Ar}$ ages (23 to $25.3 \mathrm{Ma}$; Chattian) and Rb-Sr ages (30 Ma; Rupelian) (Odin \& Kreuzer, 1988).

Based on a gravel bed at the base of the Kiel Member, observed only in one outcrop, and a thin layer of coarse sand, Vandenberghe et al. $(1998 ; 2004)$ interpreted the Edegem Member and Kiel Member as two separate incomplete sequences resulting from a competing tectonic uplift and a rising sea level. The Edegem Member displays a coarsening upwards signature in the grain size (Fig. 5), suggestive of a highstand systems tract. The log-signature suggests that maximum regression is represented by the coarser Kiel Member and a subsequent transgression marked the transition towards the Antwerpen Member. No distinct break in sedimentation can be deduced from dinoflagellate cyst biostratigraphy, indicating that the Kiel Member was deposited only slightly later than the Edegem Member (Louwye, 2000; Louwye, 2005). Taking into account the age constraints as derived above, the Edegem Member and Kiel Member could approximately be correlated to the Bur 2 and Bur 3 sequences 
as figured by Hardenbol et al. (1998, chart 2). A correlation with the sequence stratigraphic scheme by Rasmussen (2004a, 2004b), defined in Demark, proved more difficult given the absence of a precise dating of the sequence boundaries. The Edegem Member can maybe be correlated with the highstand system tract of their sequence C, while the Kiel Member would then be correlated to sequence $\mathrm{D}$

\subsubsection{Antwerpen Member}

The Antwerpen Member was observed for the first time by Nyst (1845) during the works for the fortifications around Antwerp and was called 'Sable noir du Fort d'Herenthals'. Later, Vanden Broeck (1874) renamed the unit as 'Sables à Pectunculus pilosus'. The Antwerpen Member was for the first time formally described by de Heinzelin (1956) and regarded as the upper part of the middle Miocene 'Anversien'. This view was later adopted during the International Neogene Symposium in 1961 (Tavernier \& de Heinzelin, 1963) and the definition of the member was emended by De Meuter \& Laga (1976).

The Antwerpen Member consists of dark green to blackish, medium fine-grained, slightly clayey and very glauconitic sand (De Meuter \& Laga, 1976). Characteristic are shell layers of a.o. Glycymeris baldii with a varying thickness. Layers with phosphatic concretions, friable sandstones, bones and shark teeth are observed towards the base of the member. The latter authors stipulate that no clear basal gravel is present. The average glauconite content reaches $47 \%$ (Fig. 7), which is the highest amount in any unit in the Campine Basin (Adriaens, 2015). In contrast to the Edegem Member and the Kiel Member, the Antwerpen Member contains mostly authigenic glauconite (Vandenberghe et al., 2014; Odin \& Kreuzer, 1988).

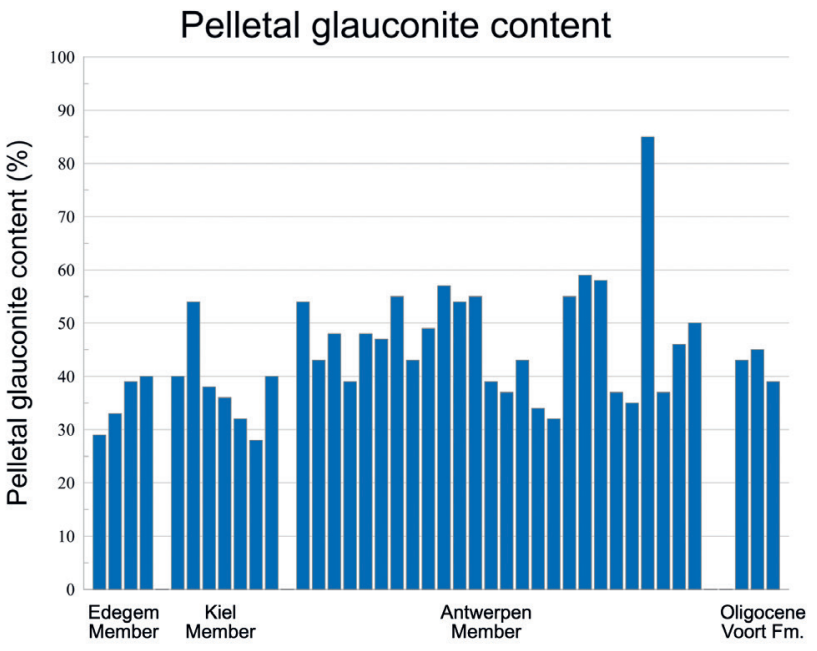

Figure 7. Pelletal glauconite contents (in wt $\%$ ) of samples of the Edegem, Kiel and Antwerpen Members of the Berchem Formation. Pelletal glauconite was isolated from the bulk sediments by magnetic separation after washing and pre-sieving at $32 \mu \mathrm{m}$. The pelletal glauconite content of three Oligocene Voort Formation samples was added for comparison.

The Antwerpen Member was examined for planktonic foraminifera by Hooyberghs (1983) in the temporary outcrop Kievitstraat, and he proposed a correlation with the N6 Globigerinoides trilobus Zone (late Burdigalian) to the N9 Globorotalia peripheroronda Zone (Langhian) of Blow (1969). Hooyberghs (1983) studied a poorly preserved foraminifera assemblage from the Antwerpen Member and noted that the planktonic foraminifera from the lower part of the member are distinctly older than those from the upper part. Hooyberghs \& Moorkens (1988) proposed in a review paper a correlation with the NPF12 Globogineroides trilobus Zone to the NPF13 Globorotalia praescitula Zone defined by Spiegler et al. (1988), also pointing towards a late Burdigalian to Langhian age. They furthermore state that the base of the Serravallian NPF14 Zone could be present. Willems et al. (1988) attributed the benthic foraminiferal assemblage of the Antwerpen Member to the
B7 Zone of the IGCP 124 Working Group. Based on benthic foraminifera, De Meuter \& Laga (1976) correlated the Antwerpen Member from the Rivierenhof outcrop (BGD 028E0499, DOV $\mathrm{kb} 15 \mathrm{~d} 28 \mathrm{e}-\mathrm{B} 580$ ) with the mid-Miocene Uvigerina tenuipustulata - Elphidium inflatum Assemblage Zone. Doppert et al. (1979), based on De Meuter \& Laga (1976), formalized the latter zone as the BFN2 Uvigerina tenuipustulata - Elphidium inflatum Zone. The calcareous nannoplanton from a temporary outcrop at Borgerhout led Martini \& Müller (1973) to propose a correlation with the NN4 Zone (late Burdigalian to Langhian). Verbeek et al. (1988) confirmed this attribution in a review paper.

Dinoflagellate cysts from the Antwerpen Member were studied in the three temporary outcrops Grote Steenweg, Kievitstraat and Rivierenhof (Louwye et al., 2000) (Fig. 2, see also De Meuter et al., 1976). The Labyrinthodinium truncatum Zone (Dybkjær \& Piasecki, 2010), defined from the lowest occurrence (LO) of the eponymous species to the LO of Unipontidinium aquaeductus and dated as early Langhian (15.97 Ma to $14.8 \mathrm{Ma}$ ), was recognized in all three outcrops. The superjacent Unipontidinium aquaeductus Zone, defined from the LO of the eponymous species to the LO of Achomosphaera andalousiensis and dated as early Langhian to early Serravallian (14.8 Ma to $13.2 \mathrm{Ma}$ ), is only present in the Rivierenhof outcrop. The uppermost part of the Antwerpen Member in the Rivierenhof outcrop holds both Achomosphaera andalousiensis and Cannosphaeropsis passio and can thus be allocated to the Achomosphaera andalousiensis Zone dated between 13.2 Ma to $12.8 \mathrm{Ma}$ (early to mid-Serravallian) (Fig. 6). The Antwerpen Member was thus deposited between 15.97 Ma and 12.8 Ma (Langhian - mid-Serravallian).

The radiometric datings of glauconites from the Antwerpen Member in temporary outcrops along the highway around the city (Fig. 2) give a K-Ar age of $20 \mathrm{Ma}$ (Burdigalian) and a Rb-Sr age of 18.5 Ma to $21.5 \mathrm{Ma}$ (Odin \& Kreuzer, 1988). In the present time scale (ICS chart 2020/03) the Antwerpen Member would be of latest Aquitanian to mid-Burdigalian age. This age assessment contrasts with the biostratigraphical age interpretation indicating a Langhian to mid-Serravallian age. It should be noted that the Antwerpen Member is notoriously rich in glauconite pellets with many samples between $50 \%$ and $60 \%$ pellets and some samples with a higher pellet content of more than $80 \%$ (Bastin, 1966). The comparison between the grain shapes and the size distribution shapes of glauconite pellets and quartz grains in samples of the three members of the Berchem Formation confirms the reworking of the pellets in the Edegem Member and Kiel Member and the authigenesis in the Antwerpen Member (Vandenberghe et al., 2014; Adriaens, 2015). The obvious discrepancy between the radiometric and biostratigraphical ages indicates that the authigenic glauconites in the Antwerpen Member also contain reworked pellets, shifting the radiometric age to somewhat older ages.

The Antwerpen Member is the third incomplete sequence of the lower-middle Miocene, due to continuing tectonic uplift of the Brabant Massif to the south. The presence of authigenic glauconite, phosphate pebbles and hardgrounds near the base of the Antwerpen Member are interpreted as an indication of a new transgressive phase, i.e. a transgressive surface (see also fig. 11 in Everaert et al., 2020, this volume). Each member of the Berchem Formation was thus considered to represent the transgressive and or highstand phase of a different sequence and the base of the Antwerpen Member was correlated to the Bur 5/Lan 1 (16.5 Ma) sequence boundary by Vandenberghe et al. (1998; 2004). Taking into account the biostratigraphic age range for the deposition of the Antwerpen Member as discussed above, the sedimentation of the Antwerpen Member took place during three sequences as defined by Hardenbol et al. (1998, chart 2): Bur 5/Lan 1, Lan 2/ Ser 1 and Ser 2. The boundary of sequence E of Rasmussen (2004a, 2004b) (see Fig. 6) is interpreted by the latter author as corresponding to a major transgression in the North Sea Basin and correlated to the mid-Miocene unconformity (MMU). The lower part of the sequence reflects a major transgression and resulted in the deposition of glauconite-rich sediments, similar to the Antwerpen Member. In the Belgian and Dutch glauconite-rich Neogene sections (see also Munsterman et al., 2019) the MMU is however situated at a major hiatus between the Berchem and Diest Formations at the turn of the Serravallian to the Tortonian. 


\subsubsection{Zonderschot Member}

The Zonderschot Member occurs in the area of Heist-op-denBerg in the south of the Berchem Formation outcrop area. The Zonderschot Member was first described during construction works for a gas pipeline and formally defined by De Meuter \& Laga (1976) as a dark green, rather fine-grained, clayey, slightly ligniferous, very glauconitic sand. The micaceous sediment is very rich in homogeneously dispersed shells (De Meuter \& Laga, 1976). The formation rests unconformably on the lower Oligocene Boom Formation and is overlain to the northeast and east by the upper Miocene Diest Formation. The Zonderschot Member wedges out to the south. The unit was described in detail in a $7 \mathrm{~km}$ long trench by Huyghebaert \& Nolf (1979). Based on the analyses of these authors, the Zonderschot Member is finer grained than the other members of the Berchem Formation, with a mode between 125 and $17 \mu \mathrm{m}$ and a higher clay content of approximately $12 \%$ (Fig. 4 ).

Hooyberghs (1980) recognized in a temporary outcrop at Heist-op-den-Berg in the Zonderschot Member the regional Globigerinoides trilobus trilobus/Globigerinoides altiaperturus Biozone (Blow, 1969), a zone correlated later by Hooyberghs (1996b) to Biozone N6 or Biozone N7, which would then indicate at least a Burdigalian age for the deposits. De Meuter \& Laga (1976), Doppert et al. (1979) and De Meuter (1980) examined the benthic foraminifera from the Zonderschot Member in a temporary outcrop and correlated the sand with the middle Miocene Uvigerina tenuipustulata - Elphidium inflatum BFN2 Zone.

The calcareous nannoplankton from the Zonderschot Member indicates the presence of the NN4 Zone, and a late Burdigalian to early Langhian age could be inferred (Verbeek et al., 1988). Nolf (1977), Huyghebaert (1978), and Huyghebaert \& Nolf (1979) studied the teleost otoliths from the type-area of the Zonderschot Member and inferred deposition during middle Miocene times. Gaemers (1988) correlated the Zonderschot Member with otolith Zone 12 (German regional stages Oxlundian, late Hemmoorian or late Burdigalian, earliest Langhian). Spiegler (2001) recorded the Bolboforma rotundata Zone in the Zonderschot Member and inferred an early Miocene age.

Louwye (2000) analyzed the dinoflagellate cysts of the Zonderschot Member from two locations in the Zonderschot area (DOV TO-19720101 and DOV kb24d59e-B180) and correlated the deposits with the Distatodinium paradoxum DN4 Zone by de Verteuil \& Norris (1996). The Langhian Labyrinthodinium truncatum Zone by Dybkjær \& Piasecki (2010), defined in the Danish part of the North Sea Basin, is correlatable with the latter zone, but is more detailed in terms of the assemblage (Fig. 6). The age of the zone is early Langhian (15.97 Ma to $14.8 \mathrm{Ma}$ ). The radiometric dating of the Zonderschot Member based on glauconites is considered as reliable with an age of $15.5 \mathrm{Ma}$ (early Langhian) (Odin \& Kreuzer, 1988).

The Zonderschot Member is coeval with the lower part, and the lower sequence (Bur 5/Lan 1), of the Antwerpen Member (Louwye, 2000), and differs from the latter by the presence of mica and lignite fragments, a statement previously advanced by Huyghebaert \& Nolf (1979).

\subsection{The Berchem Formation outside the type area}

The Berchem Formation was recovered in the Campine area, i.e. the area north and east of Antwerp, in numerous boreholes, drilled a.o. by the Geological Survey of Belgium (Fig. 1). In the records of the Geological Survey of Belgium, the lower and middle Miocene deposits are usually referred to as Berchem Formation with only sporadic reference to members, (e.g. "Sands of Antwerpen s.l." in the Poederlee boreholesee below; "Antwerpen sands" and "Edegem sands" in the Kalmthout borehole-see below). The Berchem Formation was analyzed biostratigraphically with dinoflagellate cysts in eight cores from the Campine area, from which six by Louwye (2005) at Kalmthout (BGD 006E0110, DOV kb7d6e-B239), Rijkevorsel (BGD 016E0153, DOV kb8d16e-B36), Oostmalle (BGD 029E0249, DOV kb16d29e-B276), Poederlee (BGD 030W0300, DOV kb16d30w-B315), Retie (BGD 031W0243, DOV kb17d31w-B228) and Mol (BGD 031W0221, DOV kb17d31w-B212) (Fig. 8), and two by Munsterman \& Deckers
(2020) at Mol (ON-Mol-1, BGD 031w0314, DOV ON-Mol-1) and Weelde (BGD 008E0159, DOV kb8d8e-B161). Two of these cores, the Rijkevorsel core and the Poederlee core were biostratigraphically analyzed with foraminifera and were reported on in the logs (unpublished data by P. Laga).

Munsterman \& Deckers (2020) recorded the oldest Miocene (early Aquitanian) at the very base of the Weelde borehole in one sample (Fig. 1). The oldest Miocene deposits noted by Louwye (2005) are present in the Kalmthout well in the Campine area, the Antwerp area and more to the south in the Burcht (DOV TO20050101A) and Terhagen area (DOV TO-20050101B) (Fig. 1), and hold the early Burdigalian Cordosphaeridium cantharellus Zone (19 Ma to $18.4 \mathrm{Ma}$, see above). In the Antwerp area, the Cordosphaeridium cantharellus Zone is recognized in the Edegem Member. The superjacent mid-Burdigalian Exochosphaeridium insigne Zone (18.4 Ma to $17.8 \mathrm{Ma}$ ) has a large geographical extent and is present from the Kalmthout well in the north to Terhagen in the Antwerp area in the south (i.e. the southernmost extent of the Miocene), and to the east as far as Poederlee (Fig. 1). The late Burdigalian Cousteaudinium aubryae Zone (17.8 Ma to $15.97 \mathrm{Ma}$ ) is present in all wells in the central to eastern part of the Campine area as far as Retie, and is particularly well developed in the Oostmalle well with a thickness of circa $12 \mathrm{~m}$. In the Antwerp area, both the Exochosphaeridium insigne Zone and the Cousteaudinium aubryae Zone are recognized in the Kiel Member. The lower Miocene foraminifera Zone Trifarina gracilis rugulosa - Elphidium ungeri was recognized in the Rijkevorsel and Poederlee wells at comparable depths of the E. insigne and C. cantharellus Zones.

The superjacent early Langhian Labyrinthodinium truncatum Zone (15.97 Ma to 14.8 Ma) and early Langhian to early Serravallian Unipontidinium aquaeductus Zone (14.8 Ma to 13.2 Ma) are present in the entire Campine area with moderate thickness but are best developed in the Oostmalle well with a thickness of $4 \mathrm{~m}$ and $3 \mathrm{~m}$, respectively. The youngest midMiocene biozone is the early to mid-Serravallian Achomosphaera andalousiensis Zone (13.2 Ma to $12.8 \mathrm{Ma}$ ) in the Kalmthout and Retie wells, and does not exceed $1.5 \mathrm{~m}$. In the type area of the Berchem Formation, the mid-Miocene Labyrinthodinium truncatum, Unipontidinium aquaeductus and Achomosphaera andalousiensis Zones are recognized in the Antwerpen Member. The dinoflagellate cyst zonation corroborates the presence of the mid-Miocene foraminifera Zone Uvigerina tenuipustulata Elphidium inflatum Zone in the Rijkevorsel and Poederlee wells at comparable depths of the above-mentioned dinocyst zones.

The Miocene transgression thus entered northern Belgium from a north to northwestern direction. Early Aquitanian deposits are recorded in the base of the Weelde borehole in the eastern Campine area near the border with The Netherlands. The oldest deposits of the Berchem Formation in the western Campine area are recorded in the Kalmthout area and are coeval with the Edegem Member of the type area. It is only during mid- and late Burdigalian time that the sea transgressed to the east as far as Retie, and deposited sediments coeval with the Kiel Member of the type area. The thickest Burdigalian deposits are present in the Oostmalle area. Langhian and early Serravallian deposits, coeval with the Antwerpen Member in the type area, have a fairly constant and moderate thickness ranging between circa $7 \mathrm{~m}$ and $4 \mathrm{~m}$ in the Campine area.

\subsection{Bolderberg Formation}

\subsubsection{The formation, sedimentology and wireline log signature}

The Bolderberg Formation was described for the first time as 'Boldérien' by Dumont (1849) who assigned a Miocene age to the unit. Dumont (1849) already recognized the twofold division: the Elsloo gravel bed, followed by a marine, glauconitic lower unit and an upper lignitic, sandy unit which he considered as fluviatile in origin. The Bolderberg Formation was subsequently the subject of many studies, and the stratigraphic position of the formation switched from the Miocene to the Pliocene, and back to the Miocene. A key observation was made by Halet (1935) during the digging of a mine shaft at Houthalen in the coal mining district of the Campine area, where the superposition of the lower glauconitic, marine sand and the superjacent non-marine sand was observed for the first time. Halet (1935) advanced furthermore 
NW

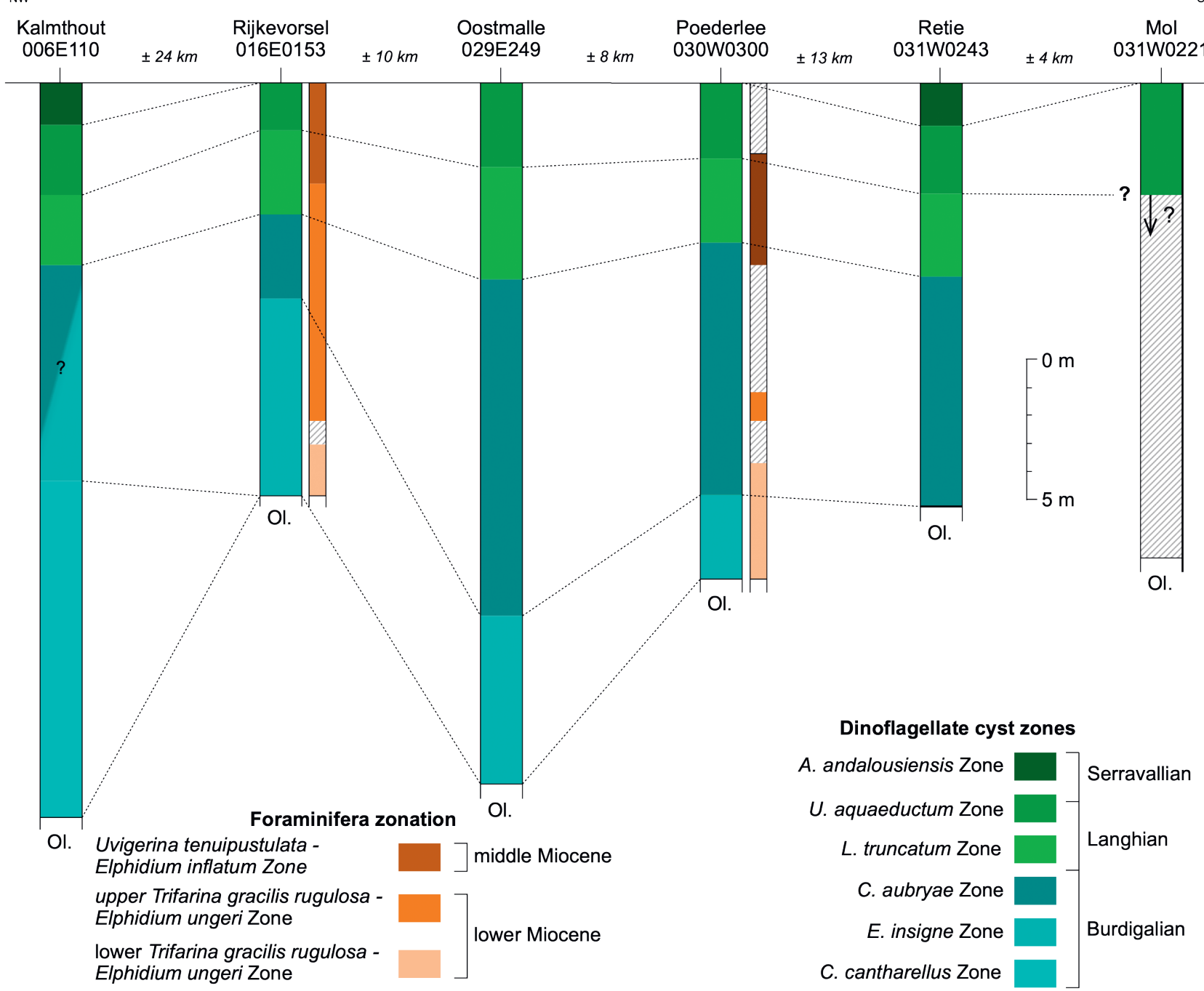

Figure 8. Distribution of the lower and middle Miocene dinoflagellate cyst zones in the Campine area in a NW-SE transect, after Louwye (2005), and based on the dinoflagellate cyst zonation by Dybkjær \& Piasecki (2010). Foraminifera zonation after De Meuter \& Laga (1976), based on unpublished data from the Geological Survey of Belgium for the Poederlee borehole (DOV kb16d30w-B315 and Rijkevorsel borehole (DOV kb8d16e-B36). Hatched interval: not studied. See Fig. 1 for locations of the boreholes.

a correlation of the marine 'Boldérien' with the 'Anversien' (see above), and indirectly attributed a middle Miocene age. De Heinzelin \& Glibert (1956) introduced the 'Boldérien' as a stratigraphic entity consisting of a basal gravel, a marine lower part and an upper continental part.

The Bolderberg Formation was formally defined by De Meuter \& Laga (1976) and re-iterated by Laga et al. (2001) as a succession of marine to continental deposits. The type locality is the village Bolderberg in the eastern Campine area. The Bolderberg Formation occurs furthermore in the subsoil of the central and eastern part of the Limburg province with outliers in the hills of the southern part of the Limburg province and the eastern part of the Flemish Brabant province (Deckers et al., 2019).

The typical marine-continental cycle was originally used to subdivide the Cenozoic in the Belgian Basin (Rutot, 1883) and was also used in the former 1:40 000 mapping. Gullentops (1963, fig. 4) used the cycle as a sedimentary model for the Cenozoic in north Belgium. The basal Elsloo gravel consists of rounded pebbles and shark teeth, and is followed by dark green, glauconitic, slightly ligniferous, fossiliferous, medium fine-grained sand with a minor clay content. Micaceous intercalations are present. This lower part of the Bolderberg Formation passes gradually into a white, and rather coarse grained sand with lignite intercalations and glassy quartzite layers. De Meuter \& Laga (1976) defined two members: the lower glauconite bearing Houthalen Member and the upper quartz-rich, pale yellow to white Genk Member.
Within the Genk Member a very white silica sand occurs which was informally called Opgrimbie sand or Opgrimbie facies.

A third member, the Opitter member, was proposed by Gullentops \& Huyghebaert (1999) and mapped by Sels et al. (2001) on the geological map 18-10 Maaseik-Beverbeek. The proposal was based on the stratigraphic interpretation of an outcrop in the Opitter Molen sand pit by Gullentops (1963), and follows previous interpretations (a.o. de Heinzelin, 1963a). However, Houthuys \& Matthijs (2020, this volume) and Dusar (archives BGD 048E0294) have argued that the Opitter sand, interpreted as part of the Bolderberg Formation in the sand pit, is erroneous. In a recently drilled well at Opitter (BGD 048E0294, DOV 48E0294), the stratigraphic sequence consisting of the Bolderberg, the Diest and the Kasterlee Formations can unequivocally be identified and is coherent with the regional stratigraphy at the southwestern side of the Neeroeteren Fault, thus rendering an additional fault superfluous.

Based on only three samples, the Houthalen Member of the Bolderberg Formation has a modal grain size of $172 \pm 12 \mu \mathrm{m}$, a clay content of $2.1 \pm 0.7 \%$ and a D90 of $411 \pm 274 \mu \mathrm{m}$ (Verhaegen, 2020, this volume). One of those samples has a second coarse mode of $623 \mu \mathrm{m}$ explaining also the large variation in D90. However, these three samples which are all from the Wijshagen borehole (BGD 048W0180, DOV kb18d48w-B181), should be reconsidered as representing the Genk Member rather than the Houthalen Member (Deckers \& Louwye, 2019). Based on samples of the Opgrimbie quarry, Gullentops (1963, 1972- 
1973 ) reported a modal grain size of approximately $215 \mu \mathrm{m}$ for the Opgrimbie facies. A sample from this facies in the Wijshagen borehole has a modal grain size of $296 \mu \mathrm{m}$, a clay content of only $0.7 \%$ and a D90 of $433 \mu \mathrm{m}$. Grain size data in Adriaens (2015) agree well with the data given above. The Genk Member has a similar smectite dominated clay mineralogy to the Houthalen Member and Berchem Formation, whereas the Opgrimbie facies has a different, kaolinite and illite-rich, clay mineralogy, probably due to a combination of a more southern source and intense leaching (Adriaens, 2015). The clay mineralogy indicates a coastal setting for the Genk Member and a fully continental setting for the Opgrimbie facies (Adriaens, 2015; Adriaens \& Vandenberghe, 2020, this volume). In the Bolderberg Formation, highest glauconite values (below 20\%) are recorded in the Houthalen Member, while the Genk Member contains no or only very limited amounts of glauconite. The non-glauconite fraction of all units is dominated by quartz. Bulk mineralogical data are available for the fraction $<32 \mu \mathrm{m}$ (Adriaens, 2015). The mineralogy $(<32 \mu \mathrm{m})$ of the Houthalen Member is very similar to that of the Berchem Formation. However, the carbonate amount is very low $(<1 \%)$ and consists only of siderite. The Genk Member is significantly less rich in clay minerals $(<50 \%)$ and does not contain any glauconite minerals (Fe-rich clays). In contrast, the Genk Member does contain more secondary sulfate minerals and it has a larger amorphous content. The mineralogy of the Opgrimbie facies is similar to that of the Genk Member but without sulfates and with an increased kaolinite content. Compared to the Berchem Formation, a larger amount of $\mathrm{Al}_{2} \mathrm{SiO}_{5}$ polymorphs (kyanite, sillimanite and andalusite), staurolite and ultrastable minerals is recorded in the Bolderberg Formation. These differences from the Berchem Formation are apparent in the marine Houthalen Member but become even stronger in the continental Genk Member. The Berchem Formation is characterized by a large amount of epidote, amphiboles and garnet, making up on average more than $50 \%$ of the transparent heavy mineral composition (Verhaegen et al., 2019; Verhaegen, 2020 , this volume). The difference between the two formations can be explained by the more southern location of the Bolderberg Formation, near the Roer Valley Graben, close to the input of sediments from the south through the Rhine-Meuse river system and local rivers draining the Ardennes and Brabant Massif (Verhaegen et al., 2019; Verhaegen, 2020, this volume).

The lower boundary of the Bolderberg Formation with the Oligocene Voort or Eigenbilzen Formations is not easy to delineate on geophysical log data, but regularly coincides with an upwards increase in gamma ray values and decrease in resistivity values (Deckers et al., 2019) (Fig. 9). The lower part of the Bolderberg Formation consists of high gamma ray and relatively low resistivity values of the glauconite-rich, clayey, fine-grained Houthalen Member. The upper-generally thicker - part consists of low to very low gamma ray and relatively high resistivity values of the glauconite-poor, coarser-grained Genk Member. The transition between the Houthalen and Genk Members is consequently expressed by a gradual upward decrease in gamma ray values and increase in resistivity. This gradual change continues in the lower part of the Genk Member, and is interpreted as representing a coarsening upwards trend (Deckers \& Louwye, 2017).

Close to RVG border fault zone, the subdivision of the Bolderberg Formation in the Houthalen and Genk Members is still clearly expressed in the lithology of the Wijshagen borehole and in the geophysical logs of the Gruitrode borehole (BGD 048W0185, DOV kb18d48W-B186; Fig. 9). However, across this fault zone in the Molenbeersel borehole Deckers \& Munsterman (2020, fig. 3) distinguished an additional $156 \mathrm{~m}$ slightly glauconitic and lignite-containing fine sand between the top of the Genk Sand and the base of the Diest Sand from which it differs by the marked increase in glauconite and therefore higher GR values in the latter. This additional $156 \mathrm{~m}$ thick interval has been a stumbling block in all previous interpretation attempts (see e.g. Demyttenaere \& Laga, 1988; Verbeek et al., 2002; Broothaers et al., 2012). Deckers \& Munsterman (2020) have argued that this additional interval is comparable to the Serravallian Vrijherenberg Sand in the Dutch stratigraphy. No comparable lithostratigraphic units of such age are known in Belgium and therefore a new lithostratigraphic unit has to be introduced. It is proposed to include this additional sand package in the Bolderberg Formation as the Molenbeersel member (see paragraph 2.3.5.).

The Bolderberg Formation is topped by the basal gravel layer of the Diest Formation. On wireline logs, the boundary between the Bolderberg Formation and Diest Formation coincides with a subtle increase in gamma ray values caused by an increase in glauconite content (Deckers \& Louwye, 2017).

\subsubsection{Houthalen Member}

The well-developed, transgressive Elsloo gravel at the base of the Bolderberg Formation consists of reworked Oligocene components, dark blue, egg-shaped, indented phosphate pebbles and shark teeth (Vandenberghe et al., 1998). Tavernier (1954) already stressed the importance of the Elsloo gravel as a reference level. These characteristic pebbles occur under a thin glauconitic sand between Leuven and Tienen (Vandenberghe \& Gullentops, 2001), while Houthuys (2014) reports similar pebbles in the Flemish Hill sand base gravel near Ronse. The Elsloo gravel is overlain by the marine Houthalen Member: a dark green, often clayey, medium fine-grained sandy unit, micaceous, slightly ligniferous and glauconitic. Similar to the Berchem Formation, dispersed and concentrated mollusks occur which are also reworked in the basal gravel of the superjacent Diest Formation (De Meuter \& Laga, 1976). The Houthalen Member has a lower average glauconite content compared to the glauconitic sand of the Berchem Formation ( $17 \%$ versus $>30 \%$ ), which can be explained by a more landward position of the Bolderberg Formation with a stronger continental influence (Adriaens, 2015). The presence of lignite in the Houthalen Member furthermore testifies of a more proximal depositional setting, contrasting with the open marine depositional setting of the Berchem Formation (Deckers \& Louwye, 2017).

A first study with benthic foraminifera of the Houthalen Member led De Meuter (1970) to propose tentatively a lateral stratigraphical equivalence with the Antwerpen Member, and thus a middle Miocene age. De Meuter \& Laga (1976) recognized both in the Edegem Member and the Houthalen Member the Trifarina gracilis rugulosa - Elphidium ungeri Zone and thus lowered the stratigraphic position to the lower Miocene. De Meuter (1980) finally proposed a position in between the Edegem and Antwerpen Members. Willems et al. (1988) stated that the Houthalen Member and the Edegem Member both hold the lower Miocene interregional benthic foraminifer B7 Zone of the IGCP 124 Working Group.

Based on planktonic foraminifera, Hooyberghs \& De Meuter (1972) attributed the Houthalen Member to the upper part of the N4 Zone and N5 Zone of Blow (1969) and a stratigraphic position between the Edegem Member and Antwerpen Member was inferred. Hooyberghs (1983) made a more detailed study of the planktonic foraminifera from the Houthalen Member and recognized tentatively the N5 and the N6 Zones of Blow (1969) of Burdigalian age. Hooyberghs \& Moorkens (1988) confirmed the presence of the Burdigalian interregional NPF12 Zone (Spiegler et al., 1988) in the Houthalen Member (and in the lower part of the Antwerpen Member), while the Edegem Member holds the Aquitanian NPF11 Zone (cf. supra). In two sequence stratigraphic review papers, Vandenberghe et al. $(1998,2004)$ linked the Houthalen Member to the Edegem Member, a correlation that was not fully supported based on the recorded benthic and planktonic foraminifera which actually placed the Houthalen Member in between the Edegem and Antwerpen Member (see above). Martini \& Müller (1973) found a similar nannoplankton assemblage in the Houthalen Member and the Edegem Member, a finding that was later corroborated by Verbeek et al. (1988) who stated that both members hold the nannoplankton NN2 Zone and NN3 Zone. Wouters (1978) recognized in the Houthalen Member the ostracod Pterygocytheris continens - Kuiperiana wanneri Zone, which is correlatable to the lower Miocene U2 zone of Gramann (1988).

Louwye \& Laga (2008) analyzed the dinoflagellate cysts a section in the Wijshagen core that was considered at that time to belong to the Houthalen Member. Their analyses showed that, following the biozonation of de Verteuil \& Norris (1996), the entire analyzed section holds the DN4 and DN5 Zones and deposition 


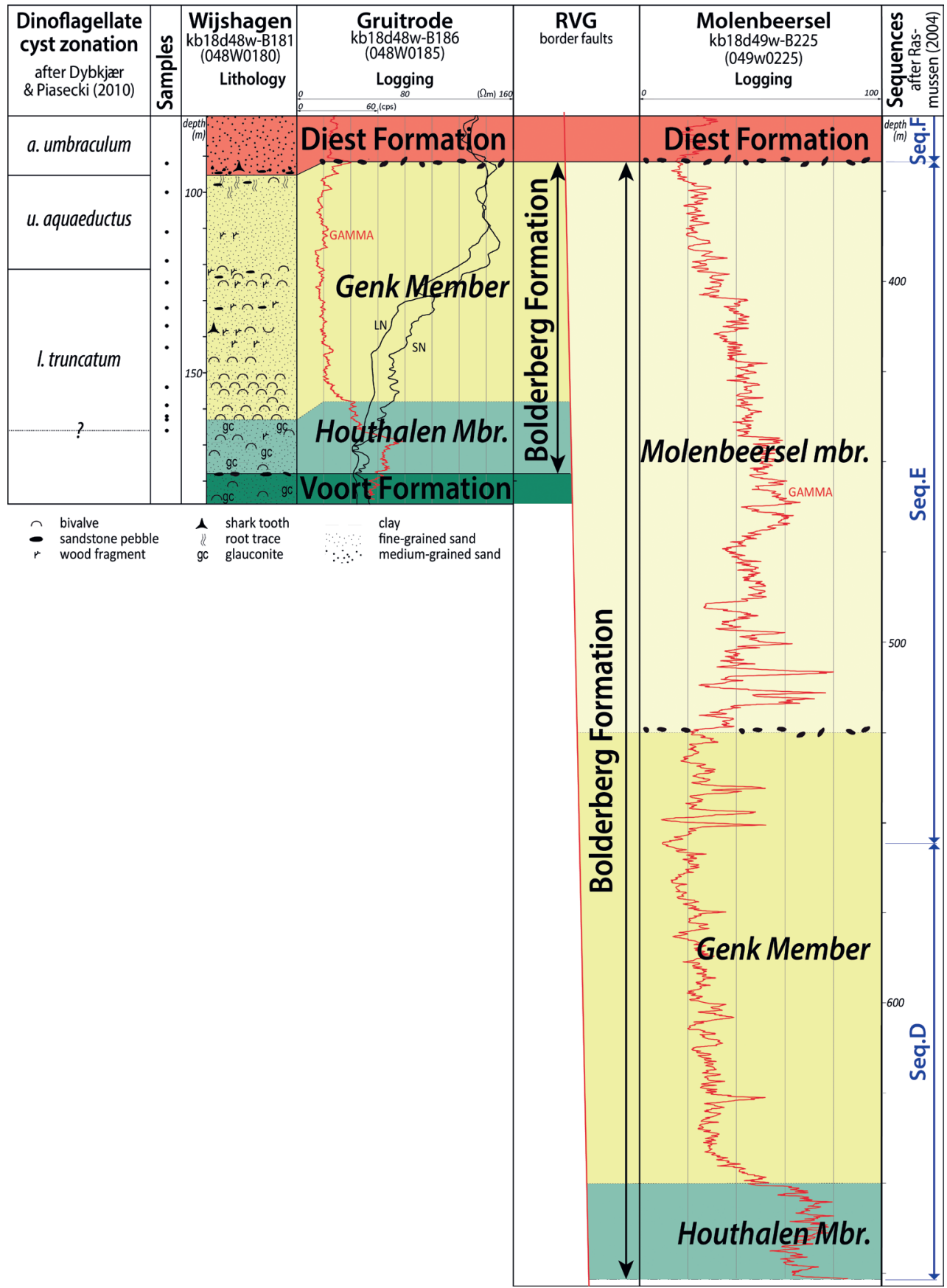

Figure 9. The Bolderberg Formation in the Wijshagen borehole and the correlations with the nearby Gruitrode borehole (according to Deckers \& Louwye, 2017) and the Molenbeersel borehole (according to Deckers \& Munsterman, 2020). The thickness of the Bolderberg Formation strongly increases from the Campine Block into the Ruhr Valley Graben as the Molenbeersel member proposed here is absent in the first and present in the latter. Dinoflagellate cyst analyses on the Wijshagen borehole were carried out by Louwye \& Laga (2008). The lowermost sample was taken in the top of the Houthalen Member, which therefore-just like the lower part of the overlying Genk Member-belong to the Labyrinthodinium truncatum Zone. Note that between the Unipontedinium aquaeductum and the Amiculosphaera umbraculum Zones, the Achomosphaera andalousiensis and Gramocysta verricula are lacking in the Wijshagen borehole.

took place some time during late Burdigalian and Langhian times. The calibrated biozonation by Dybkjær \& Piasecki (2010) indicates the presence of the lower Langhian Labyrinthodinium truncatum and lower Langhian - lower Serravallian Unipontidinium aquaeductus Zones. Louwye \& Laga (2008) suggested a major hiatus of circa 2 Ma between the Bolderberg Formation and the superjacent Diest Formation. More recently, based on a lithological re-analysis and correlation with the logged Gruitrode borehole, Deckers \& Louwye (2017) re-interpreted the lithostratigraphy of the analyzed section of the Wijshagen borehole previously analyzed by Louwye \& Laga (2008), and referred almost the entire section to the Genk Member (Figs 5, 8). Only the lowermost sample of the studied section was interpreted by Deckers \& Louwye (2017) as belonging to the Houthalen Member. However, it has to be stressed that the boundary between the Houthalen and Genk Members in the Wijshagen borehole is not sharp but gradual. In any case, the age of the Houthalen Member has to be re-assessed. According to the dinoflagellate cyst biostratigraphy of Dybkjær \& Piasecki (2010), the sole sample of the Houthalen Member in the Wijshagen borehole has an earliest Langhian age. The section of the Houthalen Member below the top sample remains unstudied for palynology and has an inferred pre-Langhian (or even Burdigalian) age (Fig. 6).
This inferred pre-Langhian (Burdigalian) age for the Houthalen Member is thus in agreement with previous biostratigraphical studies with calcareous microfossils (cf. Hooyberghs \& De Meuter, 1972; Martini \& Müller, 1973; De Meuter \& Laga, 1976; Wouters, 1978; Hooyberghs, 1983; Hooyberghs \& Moorkens, 1988; Willems et al., 1988; see also Louwye \& Laga, 2008). The Houthalen Member can be considered coeval with the Edegem and Kiel Members following the palynological analysis, and its topmost part possibly with the lowermost part of Antwerpen and Zonderschot Members

\subsubsection{Genk Member and Opgrimbie facies}

The Genk Member is the upper member of the Bolderberg Formation and consists of white to yellowish sand deposited in a more continental setting compared to the subjacent Houthalen Member. The continental influence is indicated by its quartzrich nature, lack of significant glauconite, the presence of lignite and the heavy mineral and clay mineral composition (Gullentops, 1972-1973; Verhaegen, 2020, this volume; Adriaens \& Vandenberghe, 2020, this volume). Macrofossils are generally lacking although shells are recorded at the lower part of the unit in the Wijshagen borehole (Deckers \& Louwye, 2017). Based on the dinoflagellate cyst analysis in the Wijshagen borehole by 
Louwye \& Laga (2008), correlated to chronostratigraphy using the zonation of Dybkjær \& Piasecki (2010), the Genk Member in the eastern Campine area was deposited during the Langhian to earliest Serravallian, i.e. the same time interval as the main body of the Antwerpen Member in the Antwerp area (Fig. 6). The Zonderschot Member is a coeval unit lying geographically in between.

The Genk Member has a yellowish color near the surface in the east Brabant area (Vandenberghe \& Gullentops, 2001) and on the hill tops west of Brussels ('Sables chamois', see below) (Buffel \& Matthijs, 2009). In the deeper subsurface it has a brownish-yellowish color (geological map 25 Hasselt), while in the eastern part of the same map the dominant color becomes white although some levels still have a yellowish color (Matthijs, 1999). Further eastwards, on the geological maps 26 Rekem and 18-10 Maaseik-Beverbeek the entire Genk Member is described as white sand and in this area also the very white silica glass quarried by the Sibelco company occurs.

In the Sibelco sand pit in Opgrimbie a lignite complex of about $3 \mathrm{~m}$ thickness is observed within the Genk Member (Gullentops, 1963, 1972-1973). It undoubtedly corresponds to the prograding coastal peat swamps of either Morken Lignite Seam or the Frimmersdorf Lignite Seam which have the largest geographical distribution of the lower to middle Miocene Ville Formation lignites in the Lower Rhine Graben. The Morken Lignite Seam has a middle to late Burdigalian age and the Frimmerdorf Seam has a Langhian age (Utescher et al., 2012, fig. 3). In The Netherlands the Heksenberg Member of the Groote Heide Formation consisting of white quartz-rich sand is comprised in between these two seams (van Loon, 2009; van der Meulen et al., 2009; Deckers \& Munsterman, 2020).

Matthijs (1999) further subdivided the Genk Member in the eastern part of the geological map 25 Hasselt and established a fourfold subdivision based on the occurrence of gravel layers or equivalent levels of coarser grain size. The lowest unit has a gradual transition with the underlying marine glauconitic Houthalen Member. It is separated from the overlying sand by the Terlamen gravel, which corresponds to the lower gravel in the Bolderberg section and holds silicified mollusks concentrated from older reworked Bolderberg Formation sediments (de Heinzelin, 1963b). Above the Terlamen gravel occurs about a 10 to $15 \mathrm{~m}$ thick, medium-grained white sandy unit holding lignite. It is quarried as an industrial grade silica sand, the socalled Opgrimbie silver sand. The extreme maturity of the sand is partly caused by the combined effect of a deeply weathered provenance area (Gullentops, 1963, 1972-1973) and the leaching effect of humic acids from lignite (Gullentops, 1988; van Loon, 2009). Vandenberghe et al. (1998) and van Loon (2009) assumed a Burdigalian age for the onset of the swamp conditions leading to the formation of lignite in the Opgrimbie sand, and consequently associated this lignite with the Morken Lignite Seam rather than with the Frimmersdorf Lignite Seam of Langhian age. The quartzite in the Opgrimbie sand is compared to the BraunkohlenQuartzit (Gullentops, 1963) or Nivelstein Sandstone (van Loon, 2009); it is considered as a silcrete cemented by originally abundant opal bioliths in the swamp vegetation (Gullentops, 1988), and a depositional model for the Opgrimbie sand is proposed by the latter author. Although this very white silica sand is not listed as a separate member in the stratigraphic inventories (see National Commission for Stratigraphy Belgium website, https://ncs.naturalsciences.be/paleogene-neogene/22-bolderbergformation-bb) and neither in the legends of the 1:50 000 geological maps 26 Rekem and 18-10 Maaseik-Beverbeek, it is often regarded as a separate facies, mostly as Opgrimbie sand after the now abandoned Sibelco sand pit at this locality (Gulinck, 1961; Wouters \& Vandenberghe, 1994; van Loon, 2009; Louwye et al., 2015). Other less common names for the Opgrimbie facies are Miocene glass-sand of Maasmechelen (Gullentops, 19721973), Maasmechelen Silver sand (Sels et al., 2001; Buffel et al., 2001) or 'Mechelen aan de Maas sand' (Laga, 1973). The exact lateral and vertical limits of this sand unit remain to be defined.

The white Opgrimbie sand facies is topped by the Opgrimbie gravel (Matthijs, 1999) which is exposed in the former Sibelco sand pit (Gullentops 1963, 1972-1973, 1988). The Opgrimbie gravel consists of a few well-rounded blue flint pebbles and is somewhat undulating. It is the only gravel level continuous enough to be mapped on the geological map 26 Rekem (Buffel et al., 2001). On the geological maps 26 Rekem and 18-10 MaaseikBeverbeek the Opgrimbie gravel subdivides the Genk Member in two parts, BbGe a\&b. The grain size and heavy mineral composition data of both units exposed in the Sibelco sand pit at Opgrimbie are discussed by Gullentops (1963, 1972-1973). In boreholes of the geological map 25 Hasselt, an upper third gravel layer could be identified and was called the Meulenberg gravel (Matthijs, 1999). The sandy unit between the Opgrimbie and Meulenberg gravel beds is 6 to $7 \mathrm{~m}$ thick, contains some glauconite pellets and displays cross bedding structures. The base of the latter sand is exposed above the Opgrimbie gravel in the former Sibelco sand pit (Gullentops, 1963, 1972-1973, 1988). The sand above and below the Meulenberg gravel is lithologically very similar. Gulinck (1961) reports several levels of bluish flint pebbles occurring in the As area (geological map 26 Rekem) occurring about 10 to $15 \mathrm{~m}$ above the lignite zone in the white Opgrimbie sand below the Opgrimbie gravel, and about $60 \mathrm{~m}$ above the Elsloo Gravel at the base of the Bolderberg Formation.

Vandenberghe et al. $(1998,2004)$ proposed three stratigraphic sequences in the Bolderberg Formation mainly based on the section in the Sibelco sand pit and correlates the three sequences with the threefold division of the Berchem Formation. Deckers \& Munsterman (2020) correlated the main (lower to middle Langhian) coarsening upwards body of the Genk Member to the upper part of the sequence D of Rasmussen (2004a, b). The uppermost (upper Langhian) part of the Genk Member was correlated with the lower part of sequence $\mathrm{E}$ of Rasmussen $(2004 a, b)$. Although the criteria for sequence recognition remain unchanged, new detailed controls on the stratigraphic ages of the deposits, and also the refinement of the global sequence recognition in Hardenbol et al. (1998), compared to Haq et al. (1987), are required for a re-evaluation of the present sequence interpretations.

\subsubsection{The lower and middle Miocene in the Maaseik borehole}

The Maaseik cored borehole (BGD 49W0220, DOV kb18d49w-B220, Fig. 1) was drilled in the easternmost part of the Campine area near the border with The Netherlands and is structurally located on the shoulder of the Roer Valley Graben. Vandenberghe et al. (2005) reported on the Miocene, Pliocene and Quaternary deposits through a holostratigraphical multiproxy analysis. The Miocene Breda Formation was encountered between a depth of $302 \mathrm{~m}$ and $198 \mathrm{~m}$. The base of the Breda Formation was not attained during the drilling and the formation is overlain by the upper Miocene unit X (Fig. 10) (Vandenberghe et al., 2020; Louwye \& Vandenberghe, 2020, this volume). A biostratigraphical analysis with marine palynomorphs (mainly dinoflagellate cysts) was carried out following the biozonation by de Verteuil \& Norris (1996), defined in the eastern Coastal Plain of the US. The lowermost part of the sequence (samples $295.8 \mathrm{~m}$ and $292.4 \mathrm{~m}$ ) was tentatively attributed to the upper Langhianlower Serravallian DN5 Zone. The above lying sequence holds the Zones DN6 to DN9 implying a correlation with the midSerravallian to upper Tortonian.

The Breda Formation is now re-interpreted following the biozonation of Dybkjær \& Piasecki (2010) for correlation purposes with the dinoflagellate zonation of the Berchem Formation and the Bolderberg Formation discussed above. The lowermost part (samples $295.8 \mathrm{~m}$ to $279.9 \mathrm{~m}$ ) hold the Labyrinthodinium truncatum/Unipontedinium aquaductus Zones (Fig. 10). No further differentiation could be made since the key species $U$. aquaeductus was not recorded. This section of the core has an inferred Langhian to early Serravallian age. The above lying Achomosphaera andalousiensis Zone is recognized in the interval holding the three samples $(275.8 \mathrm{~m}, 270.9 \mathrm{~m}$ and $265.8 \mathrm{~m}$ ) based on the presence of the eponymous species together with Cannosphaeropsis passio and Cerebrocysta poulsenii. Both latter species have their last occurrence in this zone according to Dybkjær \& Piasecki (2010). The A. andalousiensis Zone has an early to mid-Serravallian age. The Gramocysta verricula Zone is recognized in the above lying section (samples $256.3 \mathrm{~m}$ and $245.5 \mathrm{~m}$ ). The zone has an inferred Serravallian to early Tortonian age. The above lying section until the upper boundary holds the 


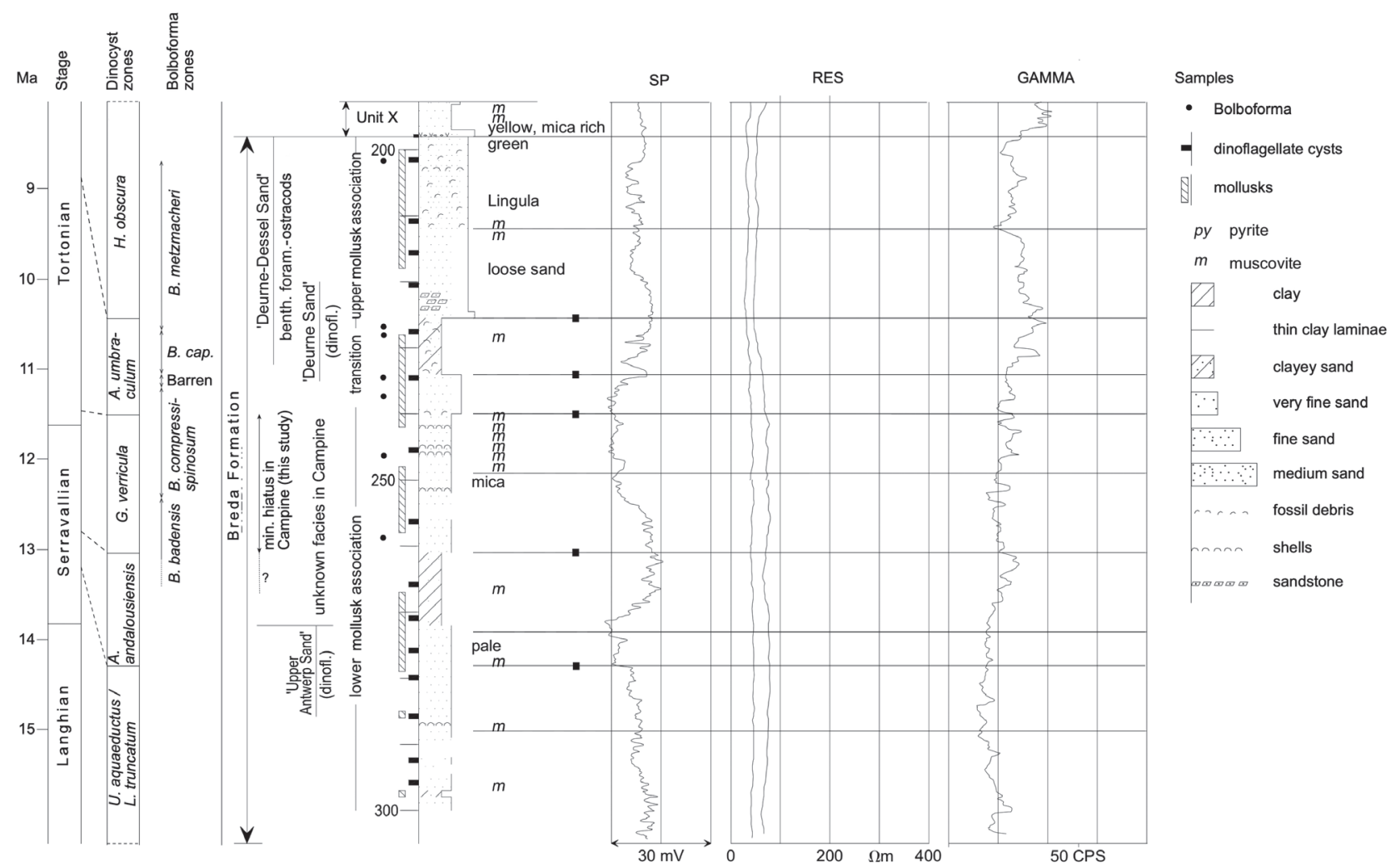

Figure 10. Lithostratigraphy, biostratigraphy, chronostratigraphy and geophysical logs of the Maaseik borehole, modified after Vandenberghe et al. (2005). Vertical dotted line: uncertain range, horizontal solid lines: correlation from lithological and geophysical boundaries as identified by Vandenberghe et al. (2005, figs $2 \& 7$ ). Note the small, black squares on the horizontal lines marking the correlation between lithology-geophysical log signatures and biozone boundaries. Dinoflagellate cyst zonation after Dybkjær \& Piasecki (2010). Bolboforma zonation after King (2016). The interval 'unknown facies in Campine' correlates with the upper part of the Molenbeersel member (see text 2.3.5.).

Tortonian Amiculosphaera umbraculum Zone (samples $234.5 \mathrm{~m}$ and $227.5 \mathrm{~m})$ and the upper Tortonian Hystrichosphaeropsis obscura Zone (samples $220.5 \mathrm{~m}$ to $191.5 \mathrm{~m}$ ). The superjacent unit X holds also the H. obscura Zone (Louwye \& Vandenberghe, 2020, this volume).

The precise boundaries between the dinoflagellate zones as indicated on Figure 10 are determined by the investigated sample depths combined with the lithological information from the core descriptions and the geophysical log signatures. The latter lithological changes and log signatures fit well with the dinoflagellate cyst zone divisions. Vandenberghe et al. (2005) already stipulated that in the Maaseik well a lithofacies unknown in Campine area is present ('unknown facies in Campine', Fig. 10). This interval in the Maaseik core corresponds partly to the $A$. andalousiensis Zone and entirely to the $G$. verricula Zone. The latter zone is indeed absent in the Antwerp area and Campine area where the youngest recognized zone is the $A$. andalousiensis Zone. Vandenberghe et al. (2005) furthermore labelled in the Maaseik core a section as "Upper Antwerp Sand" (Fig. 10) which now, after the biostratigraphic re-interpretation following Dybkjær \& Piasecki (2010) corresponds to the lower part of the A. andalousiensis Zone. The deposits in the Maaseik core holding the upper part of the A. andalousiensis Zone and the Gramocysta verricula Zone correspond thus to the minimal duration of the hiatus observed in the Antwerp and Campine areas (see above).

The Bolboforma of the Breda Formation were analyzed by Hooyberghs et al. (2004) and four biozones were recognized. The revision of the Bolboforma biozones by King (2016) is used here. From top to base following Bolboforma biozones were recognized: the Bolboforma metzmacheri Zone (201.5 $\mathrm{m}$ to $227.5 \mathrm{~m} ; 9.54 \mathrm{Ma}$ to $8.78 \mathrm{Ma}$ ), the Bolboforma capsula Zone (sample $228.5 \mathrm{~m}$; $10.5 \mathrm{Ma}$ to $9.54 \mathrm{Ma}$ ), a barren interval (sample $234.5 \mathrm{~m}$ ), the Bolboforma compressispinosa Zone (samples $237.5 \mathrm{~m}$ and $246.5 \mathrm{~m} ; 11.9 \mathrm{Ma}-11.56 \mathrm{Ma}$ ), the Bolboforma badenensis Zone (sample $259.5 \mathrm{~m}$; $12.6 \mathrm{Ma}$ to $11.9 \mathrm{Ma}$ ). The Bolboforma subfragoris zone $(11.56 \mathrm{Ma}-10.50 \mathrm{Ma})$ was not recognized between the $B$. compressispinosa and $B$. capsula zones, most probably because of the barren interval of circa
$10 \mathrm{~m}$. If the barren interval would not correspond to the missing $B$. subragoris zone but on the other hand to either the $B$. capsula or B. compressispinosa zone, a hiatus of about $1 \mathrm{Ma}$ could be present at that level. The Bolboforma zonation and stratigraphic interpretation confirms the dinoflagellate cyst interpretation notwithstanding minor inherent discrepancies related to calibration.

\subsubsection{Molenbeersel member}

The additional sand interval between $369 \mathrm{~m}$ and $525 \mathrm{~m}$ in the Molenbeersel borehole (see section 2.3.1.) is here proposed as the new Molenbeersel member. Compared to the underlying Genk Member the unit is characterized by a markedly higher GR signal (Fig. 9). This is consistent with its lithology of brown-gray to gray-green, clay- and shell-bearing silt and fine-grained sand that contains lignite and glauconite, in contrast to the quartz-rich Genk Sand. The gamma ray values in the Molenbeersel member interval increase from a basal gravel towards a maximum in the central part, which is richest in glauconite and shells (including Glycymeris) and is also micaceous. From this maximum, a decrease takes place in the gamma ray values towards the top section, which coincides with an increase in lignite. The top of the Molenbeersel member in the Molenbeersel borehole is capped by the basal gravel layer of the Diest Formation as is the case with the Genk Member in the Campine area (Fig. 9). On wireline logs, this boundary between the Bolderberg Formation and Diest Formation coincides with a subtle increase in gamma ray values caused by an increase in glauconite-content (Deckers \& Louwye, 2017). Unfortunately, no relevant biostratigraphic data are available in the Molenbeersel borehole itself for direct comparison with the nearby Dutch RVG stratigraphy or with the nearby Maaseik borehole in the Belgian RVG. Comparison with the Vrijherenberg Sand, as discussed in Deckers \& Munsterman (2020) in the borehole Groote Heide, is mainly based on the trends in the GR signal between the Genk Sand and the Diest Sand. The Vrijherenberg Sand has a Serravallian age based on dinoflagellate cysts biostratigraphy. The implied Serravallian age of the additional Molenbeersel member interval is compatible 
with the age interval of the dinoflagellate cyst hiatus between the Genk Sand and the Diest Sand in the nearby Wijshagen borehole in which the Molenbeersel member is missing (Fig. 9; Deckers \& Munsterman, 2020, fig. 3).

In the nearby Maaseik borehole the base of the upper Miocene is interpreted at circa $240 \mathrm{~m}$ depth (see 2.3.4.). The Diest Formation nature of this glauconitic sand is confirmed above $235 \mathrm{~m}$ by their calcareous microfossils content resembling the Deurne and Dessel Members of the Berchem Formation. Underlying the upper Miocene occurs fine (modal size 175$200 \mu \mathrm{m})$ and slightly glauconitic $(2-7 \%)$ sand, herein interpreted as belonging to the upper part of the Molenbeersel member, which contains in the upper part the Serravallian dinocyst zones A. andalousiensis and G. verricula of Dybkjaer \& Piasecki (2010) (Fig. 10). Part of the A. andalousiensis zone in the Maaseik core was also recognized in the Antwerpen Member of the type area (Figs 6,8 ). It is therefore reasonable to correlate indirectly the Molenbeersel member with part of the A. andalousiensis and/ or the Gramocysta verrricula Zones, i.e. the part of the core that was interpreted as "unknown facies in the Campine area" by Vandenberghe et al. (2005). A Serravallian age could be postulated for the Molenbeersel member.

\subsubsection{Heizel member or 'Sables chamois'}

Le Hon (1862) introduced the name 'Sables chamois' to describe an isolated sandy unit on the top of the hills west of Brussels (Fig. 1). The stratigraphical position of these 'Sables chamois' remained debated for many decades until Leriche (1934), based on the presence of shark teeth in the base of the deposit, proposed a correlation with the upper Miocene deposits of northern Belgium. The 'Sables chamois' were subsequently described in detail by Gulinck (1956), and de Heinzelin (1956) suggested a correlation of the 'Sables chamois' with the lignite holding Bolderberg Formation although without providing an argumentation. The 'Sables chamois' were formally re-described by De Meuter \& Laga (1976) as a yellow-brown, fine-grained sand without fossils, and they proposed informally the name Heizel sand for the unit. A gravel bed consisting of flint pebbles, shark teeth, marine mammal bone fragments, and plant fragments, already described by Leriche (1934) and Gulinck (1956), is present at the base of the unit. De Heinzelin (1963c) correlated the gravel bed at the base of the 'Sables chamois' with the Elsloo gravel at the base of the Bolderberg Formation. The gravel bed was called the Heizel gravel (Tavernier \& de Heinzelin, 1963; De Meuter \& Laga, 1976). Neither absolute nor relative biostratigraphical datings are until now available for the 'Sables chamois'.

\section{Depositional environment and geographical distribution}

\subsection{Depositional environment of the Berchem and Bolderberg Formations}

The abundance of shallow marine and inner neritic dinoflagellate cyst taxa in the Berchem Formation in the type area indicates deposition in a shallow marine environment (Louwye et al., 2000) and corroborate similar observations by Doppert et al. (1979) based on benthic foraminifera. However, the presence of oceanic dinoflagellate cyst taxa in the Antwerpen Member also testifies of a sporadic oceanic influence through currents in the shallow depositional environment of the southern North Sea Basin, most probably during periods of high sea level. The presence of abundant authigenic glauconite in the Antwerpen Member is indicative of slow sedimentation rates generally associated with a marine transgression and a depositional water depth deeper than 15 to 20 m (McRae, 1972; Giresse \& Odin, 1973).

Based on teleost otoliths, Huyghebaert \& Nolf (1979) suggested deposition of the Zonderschot Member in a warm and rather calm, littoral to neritic environment, and consider it as shallower than the depositional environment of the Antwerpen Member. This is supported by the bivalves from the Zonderschot Member indicating a similar depositional near shore environment below wave base, most probably in an embayment (Ringelé, 1974). The presence of dinoflagellate cyst species with an oceanic to outer neritic affinity in the other mainly marginal marine dinoflagellate cyst assemblage of the Zonderschot Member at the southernmost rim of the depositional area of the Berchem
Formation may represent a maximum flooding surface at the basin margin (Louwye, 2000).

The Genk Member of the Bolderberg Formation was deposited in a marginal marine depositional environment (Louwye \& Laga, 2008; Deckers \& Louwye, 2017) with limited short-lived incursions of enhanced continental and fluviatile input, as testified by the variations in marine organic-walled palynomorphs (dinoflagellate cysts, acritarchs), organic-walled non-marine and terrestrial palynomorphs (green algae, pollen), and the presence of lignite and wood fragments. A more proximal depositional setting than the more open marine depositional environment of the coeval Berchem Formation in the Antwerp area can be postulated (Deckers \& Louwye, 2017). The wellrounded and very well sorted grains point to a beach environment also suggested by the presence of gravel layers (see also van Loon, 2009). Some rare cross beds also point to a higher energy environment. The relative shallow depositional environment of the Genk Member despite the deposition during a eustatic sealevel rise related to the middle Miocene Climatic Optimum (MMCO, 17-14.5 Ma) (Zachos et al., 2001; Miller et al., 2005;), can be explained by an increase in sediment supply (Deckers \& Munsterman, 2020). A similar explanation was given for the synchronous (Langhian) shallowing in the eastern North Sea Basin (Rasmussen et al., 2010).

As mentioned above, the Zonderschot Member of the Berchem Formation probably occupies a geographically transitional position between the open marine and the marginal marine environments of the Antwerpen Member of the Berchem Formation and the Genk Member of the Bolderberg Formation, respectively.

The end of the MMCO marks the start of a eustatic sealevel fall (Zachos et al., 2001; Miller et al., 2005), and coincides with the transition from the Genk Member towards the-hereby newly introduced-Molenbeersel member of the Bolderberg Formation (Deckers \& Munsterman, 2020). The lithology of the Molenbeersel member, however, does not reflect a shallowing after the Genk Member, but on the contrary, a deepening of the depositional environment, with a return of glauconite (higher gamma ray values) and reduction of the lignite content (Fig. 9). The high gamma ray values in the central part of the Molenbeersel member probably reflect maximum flooding. This maximum flooding surface was indeed correlated by Deckers \& Munsterman (2020) with an interval in the Groote Heide borehole where a maximum of open marine dinocysts species was noted by Munsterman et al. (2019). The latter authors' dinocysts species analyses indicated a middle to early late Serravallian age for the maximum flooding surface. Also, in other parts of the North Sea Basin, such as the southern Roer Valley Graben or eastern North Sea Basin, indications for Serravallian transgression were found despite eustatic sea-level lowering (Rasmussen et al., 2010; Rasmussen \& Dybkjær, 2014; Thöle et al., 2014; Prinz et al., 2017). Rasmussen (2004a) explained the relative sea-level rise during eustatic sea-level lowering by Serravallian tectonic subsidence of the North Sea Basin. Alternatively, Deckers \& Munsterman (2020) proposed that a strong reduction of the input of sediments after the Langhian - under continued subsidencemight also explain the relative sea-level rise in the Serravallian.

The reduction in gamma ray values and increase in lignite content in the upper part of the Molenbeersel member indicates a shallowing of the depositional environment. It was probably during this shallowing that former-relatively condenseddeposits of the Molenbeersel member on top of the Campine area were eroded, as reflected by the Serravallian hiatus in the Wijshagen borehole (Deckers \& Munsterman, 2020; Fig. 9). During the Tortonian, the Berchem and Bolderberg Formations were transgressed and covered by the Diest Formation.

\subsection{Geographical distribution}

The early - middle Miocene strata encountered in the subsurface of northeastern Belgium generally dip in a northern direction. The glauconitic sand of the Berchem Formation outcrops in the city of Antwerp and is buried up to more than $100 \mathrm{~m}$ further north at the boundary with The Netherlands. As a result of differential subsidence of the Roer Valley Graben, the depth also increases in an easterly direction. Within the Roer Valley Graben itself, the 
base of the Bolderberg Formation is situated at its maximum depth of $680 \mathrm{~m}$ (Fig. 9; Broothaers et al., 2012). In their southernmost occurrences, the early to middle Miocene strata are only preserved on hill tops, up to an elevation of over +50 m reference level. The Heizel sand or 'Sables chamois' were correlated with the Bolderberg Formation (see above) and occurs on hill tops in the Brussels area (Fig. 1), while further to the east the Houthalen Member of the Bolderberg Formation was observed on the Pellenberg hill near Leuven. Other relicts are found on hilltops in southern Limburg and are locally only preserved as sandstone boulders (Creemers \& Dreesen, 2017; Fig. 1). The sand of the Opgrimbie facies subcrops and is quarried close to the Meuse river. The bluish egg-shaped pebbles at the base of the Flemish Hills formation on hilltops in northwestern Belgium are rather similar to those reported at the base of the Houthalen Member, and are suggestive of a Miocene age (Adriaens, 2015).

A strong northern heavy mineral signature characterizes glauconite-rich sand of the Berchem Formation. This signal was mixed with continental signatures in the southeastern part of the Campine area as testified by the reduced amount of glauconite, the presence of lignite in the Bolderberg Formation, especially in the Genk Member, and by the more southern continental heavy mineral signature. Seismic interpretations show that the clastics of the Genk Member were deposited as part of a northwest prograding delta-system (Deckers, 2015). According to Verhaegen (2019) the main source of sediments from the south was the weathered sedimentary cover of the Brabant Massif and Ardennes, drained by local rivers and the larger Meuse river. Further landward in the subsiding Roer Valley Graben, thick lignite seams of the Ville Formation formed in Germany (Schäfer et al., 2005). Seaward of this delta-system, the glauconitic sand of the Antwerpen Member was deposited under low sedimentation rates, indicative for sediment starvation (Deckers \& Louwye, 2019). Consequently, the boundary between the Genk and Antwerpen Members marks the maximum extent of the Langhian delta-system. In the new 3D geological model of Flanders (the G3Dv3-model) (Deckers et al., 2019), this boundary was estimated to have been situated roughly at the region where the Diest Formation strongly incised in the underlying units. This gully incision at the base of the Diest Formation was thought to be the result of early Tortonian marine ingression with strong (tidal) current erosion into latest Serravallian fluvial channels (Vandenberghe et al., 2014; Houthuys et al., 2020, this volume). Because of their relatively elevated position, the topsets of the Langhian clinoforms of the Genk Member probably formed a barrier against the Tortonian tidal currents that therefore formed the gully incisions only in their toeset region (see fig. 7 in Houthuys, 2014). The Langhian clinoforms may thereby also have redirected these Tortonian currents into the Hageland bay where maximum erosion took place.

Contrary to the relatively high-lying Campine area, the differentially subsiding Roer Valley Graben was thought not to have been influenced by the abovementioned erosive processes. Therefore, it is expected to contain the most complete Miocene succession. In the Molenbeersel borehole (Fig. 9), located in the center of the RVG near the transitional area between the Berchem and Bolderberg Formations, the upper boundary of the Genk Member is situated at a depth of ca. $520 \mathrm{~m}$ overlain by glauconitic, lignite-poor, shelly sand. The lithology of this sand is not characteristic for the Diest Formation, and in the nearby Maaseik borehole, age-equivalent strata to the Diest Formation occur at a much shallower depth according to Vandenberghe et al. (2005; base at circa $240 \mathrm{~m}$ depth). Demyttenaere \& Laga (1988) interpreted this sand as belonging to the Berchem Formation. However, compared to the Berchem Formation, the sand in the Molenbeersel borehole is much paler and contains less glauconite and some lignite. More recently, Deckers \& Munsterman (2020) correlated this sand with the early to latest Serravallian stratigraphic succession in the Groote Heide borehole located in the southeastern part of The Netherlands. They interpreted this sand as belonging to the Dutch Vrijherenberg Sands, equivalent to the German Neurath Sands, located on top of the main lignite seams. In this study, this sand interval in the Molenbeersel borehole is introduced as the Molenbeersel member. In the Campine area, the Molenbeersel member was not yet described, probably due to nondeposition or - more likely - erosion below the base of the Diest
Formation. A thin veneer of early to mid-Serravallian deposits in the Campine area was recorded only in the Kalmthout and Retie wells as belonging to the Berchem Formation (Fig. 8).

Whereas the Genk Member of the Bolderberg Formation has a different lithology than the Berchem Formation, distinguishing the Houthalen Member of the Bolderberg Formation from the Berchem Formation is more difficult. Although the lithology of the Houthalen Member and Zonderschot Member is very similar, i.e. shell-rich, dark green, clayey, glauconite-rich, micaceous fine sand with lignite, these units are thus not entirely coeval (see above) and therefore the Zonderschot Member cannot be regarded wholly as a lateral facies of the Houthalen Member. However, in the Pellenberg Hill near Leuven the characteristic Elsloo gravel was observed together with glauconitic sand and was interpreted by Verhaegen (2019) as the Houthalen Member. The heavy mineral composition of this glauconitic sand has a higher proportion of metamorphic minerals and a lower proportion of epidote, amphibole and garnet compared to the Berchem Formation, making it feasible that it belongs to the more continentally influenced Bolderberg Formation (Verhaegen, 2020, this volume). This observation would place the boundary between the Houthalen Member and the Antwerpen Member in the area where the lower to middle Miocene sediments were eroded by the Diest gully.

In the G3Dv3-model, the lower Burdigalian Edegem Member of the Berchem Formation was mapped in the area surrounding Antwerp city, from Heist-op-den-Berg in the southeast towards Brasschaat in the northwest (Deckers et al., 2019). The presence of the Edegem Member further northwest in the Harbor of Antwerp remains uncertain. In the Kalmthout borehole, coeval deposits of the Edegem Member are recorded (see 2.2.). Dinoflagellate cyst biostratigraphy indicates that in the Campine area the mid-Burdigalian to lower Serravallian deposits, i.e. deposits coeval with the Kiel and Antwerpen Members in the type area, are all lithologically regarded as Antwerpen Member, according to the borehole logs of the Geological Survey of Belgium in the absence of sediment analyses of the lithologically not much differing members. Unpublished biostratigraphical analysis of benthic foraminifera (archives Geological Survey of Belgium) in boreholes Rijkevorsel and Poederlee corroborate the dinoflagellate cyst analysis.

\section{Conclusion - proposals for stratigraphic re-evaluation and emendations}

\subsection{The status of the Kiel Member}

The Kiel and the Antwerpen Members were formally defined by De Meuter \& Laga (1976) and described in detailed lithologs by De Meuter et al. (1976). According to these authors both members are lithologically rather similar and the difference lies mainly in the absence or presence of calcareous fossils, respectively, and grain-size difference; the sand of the Kiel Member is regarded as a medium fine-grained to coarse-grained sand while the Antwerpen Member sand is medium fine-grained. Furthermore, De Meuter \& Laga (1976) state that the Kiel Member is non-fossiliferous in the southern part of the Antwerp area where the unit can readily be recognized, while more to the north and east the Kiel Member becomes fossiliferous and indistinguishable from the superjacent Antwerpen Member. Still, De Meuter et al. (1976) noted that the Kiel Member occasionally holds friable shell fragments in the southern part of the Antwerp area.

Everaert et al. (2019; 2020, this volume) and De Schutter \& Everaert (2020, this volume) recently reported in detail on several temporary outcrops of the Kiel Member in Antwerp. Lithostratigraphically, they identify the Kiel Member with respect to the overlying Antwerpen Member by a slightly paler color of the Kiel Member due to its lower glauconite and clay fraction content and its coarser-sized sand fraction. They could document a wellpreserved fauna and even correlate sections by specific mollusk levels. This correlation showed that the boundary between the Kiel and the Antwerpen Members has the geometry of an angular unconformity by the northwards disappearing of the DN3 Zone, i.e. the top part of the Kiel Member. Their data confirm that the Kiel Member, decalcified in the south, becomes fossiliferous northwards. At the time, such detailed analysis was unknown to De Meuter et al. (1976) which explains why these authors 
interpreted the entire fossiliferous temporary outcrop Kievitstraat, located north of the Kiel type area, as the Antwerpen Member noting however a layer of sandstone pebbles within the sequence. A biostratigraphical analysis with dinoflagellate cysts showed that the sediments above this pebble layer belong to the Langhian Labyrinthodinium truncatum Zone and are correlatable with other sections of the Antwerpen Member in the vicinity. However, the deposits below the pebble layer belong to the mid-Burdigalian Exochosphaeridium insigne Zone (Louwye et al., 2000) and are therefore correlatable to sections of the Kiel Member more to the south. Consequently, the late Burdigalian Cousteaudinium aubryae Zone is lacking in the Kievitstraat outcrop which implies a local considerable hiatus at this site of circa 1.8 Ma. With the present knowledge as documented above, the mid-Burdigalian sediments below the sandstone pebble layer should have been interpreted as belonging to the Kiel Member, albeit fossiliferous.

In summary, the Kiel Member is in its type area, south of the city of Antwerp, decalcified and only holds ghosts or fragile fragments of mollusks and, moreover, holds a poorly preserved dinoflagellate cyst assemblage. The taphonomic processes can be attributed to postdepositional alteration phenomena such as decalcification in combination with (mild) oxidation.

This present geometric and stratigraphic model for the relation between Kiel and Antwerpen Members needs further sedimentological, mineralogical and stratigraphical support to fully understand its evolution and determine its extension north of the city of Antwerp into the Campine.

\subsection{A new member of the Bolderberg Formation: the Molenbeersel member}

A glauconite- and lignite-bearing middle Miocene sandy unit with a thickness of $156 \mathrm{~m}$ is recorded in the Molenbeersel borehole between the Genk Member of the Bolderberg Formation and the Diest Formation (Fig. 9) (Deckers \& Munsterman, 2020). The Molenbeersel well is located in the strongest subsiding area of the Roer Valley Graben. The latter authors informally interpreted this sand as part the Dutch Vrijherenberg Sands and considered them equivalent to the German Neurath Sands. Here we propose this unit as a new lithostratigraphic unit, the Molenbeersel member, within the Bolderberg Formation (Fig. 9).

The Molenbeersel member consists of brown-gray to gray-green, clay- and shell-bearing silt and fine-grained sand, containing lignite and glauconite. The central part contains the most glauconite and shells (including Glycymeris) and is also micaceous. More lignite is present towards the top. The unit is bounded by gravel at the base and top.

The member is named after the hamlet Molenbeersel, located near the town of Kinrooi, in the province of Limburg, northeasternmost Belgium. The type section is the Molenbeersel well, DOV-code: kb18d49w-B225 and BGD-code: 049w0225 (X-coordinate: 247691.5; Y-coordinate: 207743.3; Z: $33 \mathrm{~m}$ ); interval 525-369; thickness: $156 \mathrm{~m}$ along hole. The member is present in the Roer Valley Graben (borehole Molenbeersel) and Venlo Block (borehole Groote Heide), and absent to the west in the Wijshagen borehole on top of the Campine Block. The basal Molenbeersel member is marked by a sharp increase in gamma ray values compared to the underlying Genk Member, reaching a maximum in the middle part of the unit (Fig. 9). The relatively high gamma ray values in the central part are probably caused by higher clay and glauconite contents. Near the top of the member, the gamma ray values are very low again. The boundary with the overlying Diest Formation coincides with a modest increase.

The presence of shells, glauconite and open marine dinoflagellate cysts indicates a shallow marine depositional environment. The highest glauconite content and number of open marine dinoflagellate cysts is recorded in the middle part of the member (coincident with the highest gamma ray values), interpreted as a maximum flooding surface by Deckers $\&$ Munsterman (2020). The presence of lignite and coastal palynomorphs indicate a near coastal depositional environment.

The Molenbeersel member occurs in between the underlying Genk Member of the Bolderberg Formation and the superjacent Diest Formation. This is similar to the geometric position of the Vrijherenberg Sand in the Groote Heide borehole located in the Dutch RVG. In addition, the GR evolution in the Molenbeersel member is similar to its evolution in the Vrijherenberg Sand. The Vrijherenberg Sand contains dinoflagellate cyst zones (sensu Munsterman et al., 2019) practically spanning the full range of the Serravallian time (Deckers \& Munsterman, 2020). In the nearby Maaseik borehole in the Belgian RVG the upper Miocene is immediately underlain by sand, interpreted as belonging to the uppermost part of the Molenbeersel member, of Serravallian age based on dinoflagellate cyst biostratigraphy. This makes a case for the mid-Serravallian age of the top of the Molenbeersel member. Also, more biostratigraphical and comparative sedimentological data on the Molenbeersel member are needed.

\section{Acknowledgements}

Johan Matthijs (VITO) and Isaac Berwouts (Sibelco) are thanked for information and discussion on the Opgrimbie facies and the Genk Member. Karen Dybkjær (GEUS) and Robert Speijer (KU Leuven) are thanked for their constructive reviews.

\section{References}

Adriaens, R., 2015. Neogene and Quaternary clay minerals in the southern North Sea. Unpublished Ph.D. Thesis, KU Leuven, Leuven, 272 p.

Adriaens, R. \& Vandenberghe, N., 2020. Quantitative clay mineralogy as a tool for lithostratigraphy of Neogene Formations in Belgium: a reconnaissance study. Geologica Belgica, 23/3-4, this volume. https://doi.org/10.20341/gb.2020.018

Amorosi, A., 1997. Detecting compositional, spatial, and temporal attributes of glaucony: a tool for provenance research. Sedimentary Geology, 109, 135-153. https://doi.org/10.1016/S00370738(96)00042-5

Bastin, A., 1966. Sedimentpetrologie van de Zanden van Edegem en de Zanden van Antwerpen. Het Ingenieursblad, 35, 50.

Blow, W., 1969. Late middle Eocene to Recent planktonic foraminiferal biostratigraphy. In Bronnimann, P. \& Renz, H. (eds), Proceedings of the First International Conference on Planktonic Microfossils, Geneva. Brill, Leiden, 199-421.

Broothaers, M., Deckers, J., Lagrou, D. \& Matthijs, J., 2012. 3D-lagenmodel van de Tertiaire afzettingen in de Roerdalslenk in Vlaanderen. VITO, Mol, VITO-rapport 2012/SCT/R/191, 58 p.

Buffel, P. \& Matthijs, J., 2009. Toelichtingen bij de geologische kaart van België, Vlaams Gewest: kaartblad 31-39, Brussel - Nijvel [1/50 000]. Belgische Geologische Dienst en Ministerie van de Vlaamse Gemeenschap, Afdeling Natuurlijke Rijkdommen en Energie, Brussel, $53 \mathrm{p}$

Buffel, P., Claes, S. \& Gullentops, F., 2001. Toelichtingen bij de geologische kaart van België, Vlaams Gewest: kaartblad 26, Rekem [ $1 / 50$ 000]. Belgische Geologische Dienst en Ministerie van de Vlaamse Gemeenschap, Afdeling Natuurlijke Rijkdommen en Energie, Brussel, 56 p.

Cogels, P. \& Van Ertborn, O., 1879. Note sur les formations géologiques des environs d'Anvers. Bulletin de la Société géographique d'Anvers, 3, 346-350.

Creemers, G. \& Dreesen, R., 2017. De mysterieuze stenenconcentraties van Diepenbeek: een Limburgs 'Stonehenge' of natuurfenomeen? Natuuronderzoek Limburg, 2-25.

Deckers, J. 2015. Middle Miocene mass transport deposits in the southern part of the Roer Valley Graben. Marine and Petroleum Geology, 66, 653-659. https://doi.org/10.1016/j.marpetgeo.2015.07.006

Deckers, J. \& Louwye, S., 2017. A reinterpretation of the ages and depositional environments of the lower and middle Miocene stratigraphic records in a key area along the southern margin of the North Sea Basin. Geological Magazine, 156, 525-532. https://doi. org/10.1017/s0016756817000991

Deckers, J. \& Louwye, S., 2019. Late Miocene increase in sediment accommodation rates in the southern North Sea Basin. Geological Journal, 55, 728-736. https://doi.org/10.1002/gj.3438

Deckers, J. \& Munsterman, D., 2020. Middle Miocene depositional evolution of the central Roer Valley Rift System. Geological Journal. https://doi.org/10.1002/gj.3799

Deckers, J., De Koninck, R., Bos, S., Broothaers, M., Dirix, K., Hambsch, L., Lagrou, D., Lanckacker, T., Matthijs, J., Rombaut, B., Van Baelen, K. \& Van Haren, T., 2019. Geologisch (G3Dv3) en hydrogeologisch (H3D) 3D-lagenmodel van Vlaanderen. Studie uitgevoerd in opdracht van het Vlaams Planbureau voor Omgeving, departement Omgeving en de Vlaamse Milieumaatschappij. VITO, Mol, VITOrapport 2018/RMA/R/1569. 
de Heinzelin, J., 1956. Considérations nouvelles sur le Néogène de l'Ouest de 1'Europe. Bulletin de la Société belge de Géologie, de Paléontologie et d'Hydrologie, 64/3, 463-476.

de Heinzelin, J., 1963a. Moulin d'Opitter. Compte-rendu des excursions. Point 10 de la carte-itinéraire. In Symposium sur la stratigraphie du Néogène nordique, Gand 1961. Société belge de Géologie, de Paléontologie et d'Hydrologie, Mémoires in-8 ${ }^{\circ}$, 6, 209-211.

de Heinzelin, J., 1963b. Bolderberg. Compte-rendu des excursions. Point 9 de la carte-itinéraire. In Symposium sur la stratigraphie du Néogène nordique, Gand 1961. Société belge de Géologie, de Paléontologie et d'Hydrologie, Mémoires in- $8^{\circ}, 6,206-208$.

de Heinzelin, J., 1963c. Heisel-Wemmel. Compte-rendu des excursions. Point 4 de la carte-itinéraire. In Symposium sur la stratigraphie du Néogène nordique, Gand 1961. Société belge de Géologie, de Paléontologie et d'Hydrologie, Mémoires in-8 , 6, 195-197.

de Heinzelin, J. \& Glibert, M., 1956. Lexique Stratigraphique International, Vol. 1, Europe. Fascicule 4a, France, Belgique, PaysBas, Luxembourg; 7, Tertiaire. Centre National de la Recherche Scientifique, Paris, 1-45.

De Meuter, F., 1970. The Foraminifera in the Houthalen Sands (Middle Miocene) of the Bolderberg Formation of the deepboring Helchteren. Bulletin de la Société belge de Géologie, Hydrologie et Paléontologie, 79/2, 129-132.

De Meuter, F., 1980. Benthonic foraminifera from the Miocene of Belgium. Aardkundige Mededelingen, 1, 78-170.

De Meuter, F. \& Laga, P., 1976. Lithostratigraphy and biostratigraphy based on benthonic foraminifera of the Neogene deposits in Northern Belgium. Bulletin Belgische Vereniging voor Geologie/Bulletin de la Société belge de Géologie, 85, 133-152.

De Meuter, F., Wouters, K. \& Ringele, A., 1976. Lithostratigraphy from temporary outcrops in the Antwerpen City area. Professional Paper of the Geological Survey of Belgium, 3, 1-19.

Demyttenaere, R. \& Laga, P., 1988. Breuken en isohypsenkaarten van het Belgische gedeelte van de Roerdal Slenk. Belgische Geologische Dienst Professional Paper, 234, 20 p.

De Schutter, P.J. \& Everaert, S., 2020. A megamouth shark (Lamniformes: Megachasmidae) in the Burdigalian of Belgium. Geologica Belgica, 23/3-4, this volume. https://doi.org/10.20341/gb.2020.001

de Verteuil, L. \& Norris, G., 1996. Miocene dinoflagellate stratigraphy and systematics of Maryland and Virginia. Micropaleontology, Supplement 42, 1-172. https://doi.org/10.2307/1485926

Dewaele, L., Lambert, O. \& Louwye, S., 2017a. On Prophoca and Leptophoca (Pinnipedia, Phocidae) from the Miocene of the North Atlantic realm: redescription, phylogenetic affinities and paleobiogeographic implications. PeerJ 5:e3024. https://doi. org/10.7717/peerj.3024

Dewaele, L., Amson, E., Lambert, O. \& Louwye, S., 2017b. Reappraisal of the extinct seal "Phoca" vitulinoides from the Neogene of the North Sea Basin, with bearing on its geological age, phylogenetic affinities, and locomotion. PeerJ 5:e3316. https://doi.org/10.7717/ peerj.3316

Dickin, A.P., 2005. Radiogenic Isotope Geology. Cambridge University Press, Cambridge, $492 \mathrm{p}$.

Doppert, J.W.C., Laga, P. \& De Meuter, F., 1979. Correlation of the biostratigraphy of marine Neogene deposits, based on benthonic foraminifera, established in Belgium and The Netherlands. Mededelingen Rijks Geologische Dienst, 31, 1-8.

Dumont, A., 1849. Rapport sur la carte géologique du Royaume. Bulletins de l'Académie royale des Sciences, des Lettres et des Beaux-Arts de Belgique, 16/2, 351-373.

Dusar, M. \& Vandenberghe, N., 2020. The transition from the Paleogene to the Neogene in Belgium. Geologica Belgica, 23/3-4, this volume. https://doi.org/10.20341/gb.2020.009

Dybkjær, K.\& Piasecki, S., 2010. Neogene dinocyst zonation for the eastern North Sea Basin, Denmark. Review of Palaeobotany and Palynology, 161, 1-29. https://doi.org/10.1016/j.revpalbo.2010.02.005

Eidvin, T., Ullmann, C.V., Dybkjær, K., Rasmussen, E.S. \& Piasecki, S., 2014. Discrepancy between $\mathrm{Sr}$ isotope and biostratigraphic datings of the upper middle and upper Miocene successions (Eastern North Sea Basin, Denmark). Palaeogeography, Palaeoclimatology, Palaeoecology, 411, 267-280. https://doi.org/10.1016/j. palaeo.2014.07.005

Everaert, S., De Schutter, P., Mariën, G., Cleemput, G., Van Boeckel, J., Rondelez, D. \& Bor, T., 2019. Een vroeg-Miocene fauna uit het Zand van Kiel (Formatie van Berchem) bij Post X in Berchem (Antwerpen). Afzettingen Werkgroep Tertiaire en Kwartaire Geologie, 40, 83-94.

Everaert, S., Munsterman, D., De Schutter, P., Bosselaers, M., Van Boeckel, J., Cleemput, G. \& Bor, T., 2020. Stratigraphy and palaeontology of the lower Miocene Kiel Sand Member (Berchem Formation) in temporary exposures in Antwerp (northern Belgium) Geologica Belgica, 23/3-4, this volume. https://doi.org/10.20341/ gb. 2020.025

Gaemers, P.A.M., 1988. The regional distribution of otolith assemblages; correlation of the interregional zonation with the regional lithostratigraphic formations. In Vinken, R. (ed.), The Northwest European Tertiary Basin. Geologisches Jahrbuch, Reihe A, 100, 379-389.

Giresse, P. \& Odin, S.G., 1973. Nature minéralogique et origine des glauconiesduplateaucontinentalduGabonetduCongo. Sedimentology, 20, 457-488. https://doi.org/10.1111/j.1365-3091.1973.tb01626.x

Glibert, M., 1945. Faune malacologique du Miocène de la Belgique. I. Pélécypodes. Mémoires de l'Institut Royal des Sciences naturelles de Belgique, 103, 1-263.

Glibert, M., 1952. Faune malacologique du Miocène de la Belgique. II. Gastropodes. Mémoires de l'Institut Royal des Sciences naturelles de Belgique, 121, 1-197.

Glibert, M., 1954. Pleurotomes du Miocène de la Belgique et du Bassin de la Loire. Institut royal des Sciences naturelles de Belgique, Mémoire, $129,76 \mathrm{p}$.

Gramann, F., 1988. The description of the interregional zones (K zones, U zones). In Vinken, R. (ed.), The Northwest European Tertiary Basin. Geologisches Jahrbuch, Reihe A, 100, 225-232.

Gulinck, M., 1956. Note sur la formation des 'Sables Chamois' (Néogène) de la région du Heysel. Bulletin de la Société belge de Géologie, de Paléontologie et d'Hydrologie, 65, 227-229.

Gulinck, M., 1961. Note sur le Boldérien d'Opgrimbie (Campine) et remarques sur les grès 'erratiques' du Limbourg. Bulletin de la Société belge de Géologie, de Paléontologie et d’Hydrologie, 70 , 297-301.

Gullentops, F., 1963. Etude de divers faciès quaternaires et tertiaires dans le Nord et l'Est de la Belgique. 6e Congrès International de Sédimentologie, Belgique et Pays-Bas, 20 p.

Gullentops, F., 1972-1973. Grainsize and mineralogy of Miocene glasssands of Maasmechelen, Belgian Limburg. Mededelingen Rijks Geologische Dienst, 23, 25-34.

Gullentops, F., 1988. 5.2. Opgrimbie: Bolderberg Formation. In Herbosch, A. (ed.), IAS 9th European Regional Meeting Excursion Guidebook Leuven-Belgium, September 1988. Belgian Geological Survey, Brussels, 256-257.

Gullentops, F. \& Huyghebaert, L., 1999. Neogene stratigraphy in the Itter Valley, Roer Valley Graben rim, Belgium. Aardkundige Mededelingen, 9, 143-146.

Halet, F., 1935. A propos des formations dites Casterliennes des environs d'Hérenthals en Campine. Bulletin de la Société belge de Géologie, 45, 290-297.

Haq, B.U., Hardenbol, J. \& Vail, P.R., 1987. Chronology of fluctuating sea levels since the Triassic. Science, 235, 1156-1166. https://doi. org/10.1126/science.235.4793.1156

Hardenbol, J., Thierry, J., Farley, M.B., Jacquin, T., de Graciansky, P.-C. \& Vail, P.R., 1998. Mesozoic and Cenozoic sequence chronostratigraphic framework of European Basins. In de Graciansky, P.-C., Hardenbol, J., Jacquin, T. \& Vail, P.R. (eds). Mesozoic and Cenozoic Sequence Stratigraphy of European Basins. SEPM Special publication, 60, 3-13. https://doi.org/10.2110/pec.98.02.0003

Herman, J. \& Marquet, R., 2007. Le Miocène du Deurganckdok à Doel. Memoirs of the Geological Survey of Belgium, 54, 1-149.

Hooyberghs, H., 1980. Note on the stratigraphic position of the Zonderschot Sands member of the Berchem Formation (Miocene) at Zonderschot, Belgium. Tertiary Research, 17, 15-25.

Hooyberghs, H., 1983. Contribution to the study of planktonic foraminifera in the Belgian Tertiary. Aardkundige Mededelingen, 2 , $1-131$.

Hooyberghs, H., 1996a. The stratigraphical position of the Edegem Sands (Berchem Formation, Miocene) in its type area at Wilrijk (N Belgium), based on planktonic foraminifera. Geologie en Mijnbouw, $75,33-42$.

Hooyberghs, H., 1996b. Planktonic foraminifera from the Zonderschot Sands Member of the Berchem Formation (Miocene) at Zonderschot, Belgium. Tertiary Research, 17, 15-25. 
Hooyberghs, H. \& De Meuter, F., 1972. Biostratigraphy and interregional correlation of the Miocene deposits of Northern Belgium based on planktonic foraminifera; the Oligocene-Miocene boundary on the southern edge of the North Sea Basin. Mededelingen van de Koninklijke Academie voor Wetenschappen, Letteren en Schone Kunsten van België, Klasse der Wetenschappen, 34, 3, 1-47.

Hooyberghs, H. \& Moorkens, T., 1988. Planktonic foraminifera Belgium. In Vinken, R. (ed.), The Northwest European Tertiary Basin. Geologisches Jahrbuch, Reihe A, 100, 190-198.

Hooyberghs, H., Wouters, K. \& Spiegler, D., 2004. Marine Miocene deposits in the Maaseik well $49 \mathrm{~W} / 220$ in eastern Belgium: biostratigraphy by means of various microfossil groups. Netherlands Journal of Geosciences / Geologie en Mijnbouw, 83, 39-46. https:// doi.org/10.1017/S0016774600020448

Houthuys, R. 2014. A reinterpretation of the Neogene emersion of central Belgium based on the sedimentary environment of the Diest Formation and the origin of the drainage pattern. Geologica Belgica, 17, 211-235.

Houthuys, R. \& Matthijs, J., 2020. Reinterpretation and update of the Neogene lithostratigraphy and structure of the Bree Uplift, NE Belgium. Geologica Belgica, 23/3-4, this volume. https://doi. org $/ 10.20341 / \mathrm{gb} .2020 .020$

Houthuys, R., Adriaens, R., Goolaerts, S., Laga, P., Louwye, S., Matthijs, J., Vandenberghe, N. \& Verhaegen, J., 2020. The Diest Formation: a review of insights from the last decades. Geologica Belgica, 23/3-4, this volume. https://doi.org/10.20341/gb.2020.012

Huyghebaert, B., 1978. Teleostei-otolieten en stratigrafie van de Zanden van Zonderschot (Midden Mioceen van Belgie). Unpublished Master Thesis, Universiteit Gent, Gent, 67 p.

Huyghebaert, B. \& Nolf, D., 1979. Otolithes de Téléostéens et biostratigraphie des Sables de Zonderschot (Miocène Moyen de la Belgique). Mededelingen van de Werkgroep voor Tertiaire en Kwartaire Geologie, 16/2, 59-100.

Janssen, A.W., 2001. The age of the North Sea Hemmoorian (Miocene): holoplanktonic molluscan evidence. In Vandenberghe, N. (ed.) Contributions to the Paleogene and Neogene Stratigraphy of the North Sea Basin. Proceedings of the 7th Biannual Meeting of the Regional Committees of northern Neogene and Paleogene Stratigraphy. Aardkundige Mededelingen, 11, 45-50.

Janssen, A.W. \& King C., 1988. The description of a tentative interregional pteropod (planktonic gastropods) zonation and its correlation with the regional lithostratigraphy. In Vinken, R. (ed.), The Northwest European Tertiary Basin. Geologisches Jahrbuch, Reihe A, 100, 357-366.

Keppens, E., 1981. Onderzoek van het glauconiet als geochronometer voor de $\mathrm{Rb}$-Sr dateringsmethode : toepassing op ceno- en mesozoische afzettingen in Belgische en naburige bekkens met het oog op de verbetering van de absolute tijdschaal. Unpublished Ph.D. Thesis, Geologie, Vrije Universiteit Brussel, Brussel, 315 p.

Keppens, E. \& Pasteels, P., 1982. A comparison of rubidium-strontium and potassium-argon apparent ages on glauconies. In Odin, G.S. (ed.), Numerical Dating in Stratigraphy. Wiley and Sons, Chichester, 225-243.

King, C., 2016. A revised correlation of Tertiary rocks in the British Isles and adjacent areas of NW Europe. Gale, A.S. \& Barry, T.L. (eds). Geological Society, London, Special Reports, 27, 1-719. https://doi. org/10.1144/SR27

Laga, P., 1973. The Neogene deposits of Belgium. Guidebook for the Field Meeting of the Geologists' Association London, 31 March-3 April, 1973. Geological Survey of Belgium, Brussels, 31 p.

Laga, P., Louwye, S. \& Geets, S., 2001. Paleogene and Neogene lithostratigraphic units (Belgium). Geologica Belgica, 4, 135-152. https://doi.org/10.20341/gb.2014.050

Lambert, O., 2005. Review of the Miocene long-snouted dolphin Priscodelphinus cristatus du Bus, 1872 (Cetacea, Odontoceti) and phylogeny among eurhinodelphinids. Bulletin de l'Institut Royal des Sciences Naturelles de Belgique, Sciences de la Terre, 75, 211-235.

Lambert, O., 2006. First record of a platanistid (Cetacea, Odontoceti) in the North Sea Basin: a review of Cyrtodelphis Abel, 1899 from the Miocene of Belgium. Oryctos, 6, 69-79.

Lambert, O., 2008. Sperm whales from the Miocene of the North Sea: a re-appraisal. Bulletin de 1'Institut Royal des Sciences Naturelles de Belgique, Sciences de la Terre, 78, 277-316.

Lambert, O. \& Louwye, S., 2006. Archaeoziphius microglenoideus, a new primitive beaked whale (Mammalia, Cetacea, Odontoceti) from the
Middle Miocene of Belgium. Journal of Vertebrate Paleontology, 26, 182-191. https://doi.org/10.1671/0272-4634(2006)26[182:AMANP B]2.0.CO;2

Le Hon, H., 1862. Terrains tertiaires de Bruxelles, leur composition, leur classement, leur faune et leur flore. Bulletin de la Société géologique de France, 2e série, 19, 804-831.

Leriche, M., 1934. Sur la présence dans le Brabant et le Petit-Brabant, du niveau à dents de Squales qui occupe la base du Néogène en Campine. Bulletins de la Classe des Sciences de l'Académie royale de la Belgique, 5e série, 20, 519-526.

Louwye, S., 2000. Dinoflagellate cysts and acritarchs from the Miocene Zonderschot Sands, northern Belgium: stratigraphy and correlation with contiguous areas. Geologica Belgica, 3, 55-65. https://doi. org/10.20341/gb.2014.023

Louwye, S., 2005. The Early and Middle Miocene transgression at the southern border of the North Sea Basin (northern Belgium). Geological Journal, 40, 441-456. https://doi.org/10.1002/gj.1021

Louwye, S. \& Laga, P., 2008. Dinoflagellate cyst stratigraphy and palaeoenvironment of the marginal marine Middle and Upper Miocene of the eastern Campine area, northern Belgium (southern North Sea Basin). Geological Journal, 43, 75-94. https://doi. org/10.1002/gj.1103

Louwye, S. \& Vandenberghe, N., 2020. A reappraisal of the stratigraphy of the upper Miocene unit $\mathrm{X}$ in the Maaseik core, eastern Campine area (northern Belgium). Geologica Belgica, 23/3-4, this volume. https://doi.org/10.20341/gb.2020.013

Louwye, S., De Coninck, J. \& Verniers, J., 2000. Shallow marine Lower and Middle Miocene deposits at the southern margin of the North Sea Basin (northern Belgium): dinoflagellate cyst biostratigraphy and depositional history. Geological Magazine, 137, 381-393. https://doi. org/10.1017/s0016756800004258

Louwye, S., Marquet, R., Bosselaers, M. \& Lambert, O., 2010. Stratigraphy of an early-middle Miocene sequence near Antwerp in northern Belgium (southern North Sea Basin). Geologica Belgica, 13, 269-284.

Louwye, S., Laga, P. \& Herman, J., 2015. Het Mioceen. In Borremans, M. (ed.), Geologie van Vlaanderen. Academia Press, Gent, 155-164.

Martini, E., 1971. Standard Tertiary and Quaternary calcareous nannoplankton zonation. In Farinacci, A. (ed.), Proceedings of the Second Planktonic Conference Roma 1970, 2 (ed. A.). Tecnoscienza, Roma, 739-785.

Martini, E. \& Müller, C., 1973. Nannoplankton-Gemeinschaften im Miozän und Pliozän des Nordseebeckens. Neues Jahrbuch für Geologie und Paläontologie, Monatshefte, 9, 555-564.

Matthijs J., 1999. Toelichtingen bij de geologische kaart van België, Vlaams Gewest: kaartblad 25, Hasselt [1/50 000]. Belgische Geologische Dienst en Ministerie van de Vlaamse Gemeenschap, Afdeling Natuurlijke Rijkdommen en Energie, Brussel, 104 p.

McRae, S.G., 1972. Glauconite. Earth-Science Reviews, 8, 397-440. https://doi.org/10.1016/0012-8252(72)90063-3

Miller, K.G., Feigenson, M.D., Wright, J.D. \& Clement, B., 1991, Miocene isotope reference section, Deep Sea Drilling Project Site 608: An evaluation of isotope and biostratigraphic resolution. Paleoceanography, 6, 33-52. https://doi.org/10.1029/90PA01941

Miller, K.G., Kominz, M.A., Browning, J.V., Wright, J.D., Mountain, G.S., Katz, M.E., Sugarman, P.J., Cramer, B.S., Christie-Blick, N. \& Pekar, S.F., 2005. The Phanerozoic record of global sea-level change. Science, 310, 1293-1298. https://doi.org/10.1126/science.1116412

Misonne, X., 1958. Faune du Tertiaire et du Pléistocène inférieur de Belgique (Oiseaux et Mammifères). Bulletin de 1'Institut Royal des Sciences Naturelles de Belgique, 34, 1-36.

Munsterman, D.K. \& Brinkhuis, H., 2004. A southern North Sea Miocene dinoflagellate cyst zonation. Netherlands Journal of Geosciences, 83, 267-285. https://doi.org/10.1017/S0016774600020369

Munsterman, D.K. \& Deckers, J., 2020. The Oligocene/Miocene boundary in the ON-Mol-1 and Weelde boreholes along the southern margin of the North Sea Basin, Belgium. Geologica Belgica, 23/3-4, this volume. https://doi.org/10.20341/gb.2020.007

Munsterman, D.K., ten Veen, J.H., Menkovic, A., Deckers, J., Witmans, N., Verhaegen, J., Kerstholt-Boegehold, S.J., van de Ven, T. \& Busschers, F.S., 2019. An updated and revised stratigraphic framework for the Miocene and earliest Pliocene strata of the Roer Valley Graben and adjacent blocks. Netherlands Journal of Geosciences, 98, e8. https:// doi.org/10.1017/njg.2019.10 
Nolf, D., 1977. Les otolithes des Téléostéens de l'Oligo-Miocène belge. Annales de la Société royale zoologique de Belgique, 106, 3-119.

Nyst, P.-H., 1845. Description des coquilles et des polypiers fossiles des terrains tertiaires de la Belgique. Mémoires couronnés et mémoires des savants étrangers de l'Académie royale des Sciences et BellesLettres de Bruxelles, 17, 1-697.

Nyst, H., 1861. Notice sur un nouveau gîte de fossiles se rapportant aux espèces faluniennes du Midi de l'Europe, découvert à Edeghem, près d'Anvers. Bulletins de l'Académie royale des Sciences, des Lettres et des Beaux-Arts de Belgique, 2e série, 12, 29-53.

Odin, G.S., 1982. Numerical Dating in Stratigraphy, Part 1 \& 2. Wiley and Sons, Chichester, $1040 \mathrm{p}$.

Odin, G.S. \& Kreuzer, H., 1988. Geochronology: some geochronological calibrations points for lithostratigraphic units. In Vinken, R. (ed.), The Northwest European Tertiary Basin. Geologisches Jahrbuch, Reihe A, 100, 403-410.

Odin, G.S., Gulinck, M., Bodelle, J. \& Lay, C., 1969. Géochronologie de niveaux glauconieux tertiaires du Bassin de la Belgique. Compte rendu sommaire des séances de la Société géologique de France, 6, 198-199.

Odin, G.S., Hunziker, J.C., Keppens, E., Laga P. \& Pasteels, P., 1974. Analyse radiométrique de glauconies par les méthodes au strontium et à l'argon; l'Oligo-Miocène de Belgique. Bulletin de la Société belge de Géologie, 83, 35-48.

Prinz, L., Schäfer, A., McCann, T., Utescher, T., Lokay, P. \& Asmus, S., 2017. Facies analysis and depositional model of the Serravallian-age Neurath sand, lower Rhine Basin (W Germany). Netherlands Journal of Geosciences, 96, 211-231. https://doi.org/10.1017/njg.2016.51

Rasmussen, E.S., 2004a. The interplay between true eustatic sea-level changes, tectonics, and climatical changes: What is the dominating factor in sequence formation of the Upper Oligocene-Miocene succession in the eastern North Sea Basin, Denmark? Global and Planetary Changes, 41, 15-30. https://doi.org/10.1016/j. gloplacha.2003.08.004

Rasmussen, E.S., 2004b. Stratigraphy and depositional evolution of the uppermost Oligocene - Miocene succession in western Denmark. Bulletin of the Geological Society of Denmark, 51, 89-109.

Rasmussen, E.S. \& Dybkjær, K., 2014. Patterns of Cenozoic sediment flux from western Scandinavia: Discussion. Basin Research, 26, 338-346. https://doi.org/10.1111/bre.12024

Rasmussen, E.S., Heilmann-Clausen, C., Waagstein, R. \& Eidvin, T., 2008. Tertiary of Norden. Episodes, 31, 66-72. https://doi. org/10.18814/epiiugs/2008/v31i1/010

Rasmussen, E.S., Dybkjær, K. \& Piasecki, S., 2010. Lithostratigraphy of the Upper Oligocene - Miocene succession of Denmark. Geological Survey of Denmark and Greenland Bulletin, 22, 92 p. https://doi. org/10.34194/geusb.v22.4733

Ringelé, A., 1974. Bijdrage tot de systematiek, de evolutie en de paleoekologie van Bivalvia uit Neogene afzettingen van Noord-België. Unpublished Ph.D. Thesis, KU Leuven, Leuven, Part II, 1-107.

Rutot, A., 1883. Les phénomènes de la sédimentation marine, étudiés dans leurs rapports avec la stratigraphie régionale. Bulletin du Musée royal d'Histoire Naturelle de Belgique, 2, 64-78.

Schäfer, A., Utescher, T., Klett, M. \& Valdivia-Manchego, M., 2005. The Cenozoic Lower Rhine Basin - rifting, sedimentation, and cyclic stratigraphy. International Journal of Earth Sciences, 94, 621-639. https://doi.org/10.1007/s00531-005-0499-7

Sels, O., Claes, S. \& Gullentops, F., 2001. Toelichtingen bij de geologische kaart van België, Vlaams Gewest: kaartblad 18 - 10, Maaseik Beverbeek [1/50 000]. Belgische Geologische Dienst en Ministerie van de Vlaamse Gemeenschap, Afdeling Natuurlijke Rijkdommen en Energie, Brussel, 50 p.

Spiegler, D., 2001. Bolboforma biostratigraphy in the Neogene Glauconitic Sands of Belgium. In Vandenberghe, N. (ed.), Contributions to the Paleogene and Neogene Stratigraphy of the North Sea Basin. Proceedings of the 7th Biannual Meeting of the Regional Committees of Northern Neogene and Paleogene Stratigraphy. Aardkundige Mededelingen 11, 61-68.

Spiegler, D., Gramann, F. \& Von Daniels, C.H., 1988. Planktonic foraminifera the description of the interregional zonation (NPF zones). In Vinken, R. (ed.), The Northwest European Tertiary Basin. Geologisches Jahrbuch, Reihe A, 100, 152-160.

Steeman, M.E., 2010. The extinct baleen whale fauna from the Miocene-Pliocene of Belgium and the diagnostic cetacean ear bones. Journal of Systematic Palaeontology, 8, 63-80. https://doi. org/10.1080/14772011003594961
Tavernier, R., 1954. Le Quaternaire. In Fourmarier, P. (ed.), Prodrome d'une description géologique de la Belgique. Société géologique de Belgique, Liège, 555-589.

Tavernier, R. \& de Heinzelin, J., 1963. Introduction au Néogène de la Belgique. Mémoires de la Société belge de Géologie, de Paléontologie et d'Hydrologie, série in- $8^{\circ}, 6,7-30$.

Thöle, H., Gaedicke, C., Kuhlmann, G. \& Reinhardt, L., 2014. Late Cenozoic sedimentary evolution of the German North Sea - A seismic stratigraphic approach. Newsletters on Stratigraphy, 47, 299-329. https://doi.org/10.1127/0078-0421/2014/0049

Utescher, T., Ashraf, A.R., Dreist, A., Dybkjær, K., Mosbrugger, V., Pross, J. \& Wilde, V., 2012. Variability of Neogene continental climates in Northwest Europe - A detailed study based on microfloras. Turkish Journal of Earth Sciences, 21, 289-314.

Vandenberghe, N. \& Gullentops, F., 2001. Toelichtingen bij de geologische kaart van België, Vlaams Gewest: kaartblad 32, Leuven [ $1 / 50$ 000]. Belgische Geologische Dienst en Ministerie van de Vlaamse Gemeenschap, Afdeling Natuurlijke Rijkdommen en Energie, Brussel, 77 p.

Vandenberghe, N., Laga, P., Steurbaut, E., Hardenbol, J. \& Vail, P. R., 1998. Tertiary sequence stratigraphy at the southern border of the North Sea Basin in Belgium. In de Graciansky, P.-C., Hardenbol, J., Jacquin, T. \& Vail, P.R. (eds), Mesozoic and Cenozoic Sequence Stratigraphy of European Basins. SEPM Special Publication, 60, 119-154. https://doi.org/10.2110/pec.98.02.0119

Vandenberghe, N., Van Simaeys, S., Steurbaut, E., Jagt, J.W.M. \& Felder, P.J., 2004. Stratigraphic architecture of the Upper Cretaceous and Cenozoic along the southern border of the North Sea Basin in Belgium. Netherlands Journal of Geosciences, 83/3, 155-171. https://doi.org/10.1017/S0016774600020229

Vandenberghe, N., Laga, P., Louwye, S., Vanhoorne, R., Marquet, R., De Meuter, F., Wouters, K. \& Hagemann, H.W., 2005. Stratigraphic interpretation of the Neogene marine-continental record in the Maaseik well (49W0220) in the Roer valley Graben, NE Belgium. Memoirs of the Geological Survey of Belgium, 52, 39 p.

Vandenberghe, N., Harris, W.B., Wampler, J.M., Houthuys, R., Louwye, S., Adriaens, R., Vos, K., Lanckacker, T., Matthijs, J., Deckers, J., Verhaegen, J., Laga, P., Westerhoff, W. \& Munsterman, D., 2014. The implications of K-Ar glauconite dating of the Diest Formation on the paleogeography of the Upper Miocene in Belgium. Geologica Belgica, 17, 161-174.

Vandenberghe, N., Wouters, L., Schiltz, M., Beerten, K., Berwouts, I., Vos, K., Houthuys, R., Deckers, J. Louwye, S., Laga, P., Verhaegen, J., Adriaens, R. \& Dusar, M., 2020. The Kasterlee Formation and its relation with the Diest and Mol Formations in the Belgian Campine. Geologica Belgica, 23/3-4, this volume. https://doi.org/10.20341/ gb. 2020.014

Vanden Broeck, E., 1874. Esquisse géologique et paléontologique des dépôts pliocènes des environs d'Anvers. Annales de la Société Malacologique de Belgique, 9, 87-371.

van der Meulen, M.J., Westerhoff, W.E., Menkovic A., Gruijters, S.H.L.L., Dubelaar, C.W. \& Maljers, D., 2009. Silica sand resources in the Netherlands. Netherlands Journal of Geosciences, 88, 147 160. https://doi.org/10.1017/s001677460000086x

van Loon, A.J., 2009. Unravelling the enigmas of the 'silver sands' in the Dutch/German/Belgian border area. Netherlands Journal of Geosciences, 88, 133-145. https://doi.org/10.1017/ s0016774600000858

Verbeek, J., Steurbaut, E. \& Moorkens, T., 1988. Nannoplankton Belgium. In Vinken, R. (ed.), The Northwest European Tertiary Basin. Geologisches Jahrbuch, Reihe A, 100, 267-273.

Verbeek, J.W., de Leeuw, C.S., Parker, N. \& Wong, Th.E., 2002. Characterisation and correlation of Tertiary seismostratigraphic units in the Roer Valley Graben. Netherlands Journal of Geosciences / Geologie en Mijnbouw, 81, 259-166. https://doi.org/10.1017/ S0016774600022393

Verhaegen, J., 2019. Quantitative sediment provenance and volumetric reconstruction: application to the Miocene of the southern North Sea Basin. Unpublished Ph.D. Thesis, KU Leuven, Leuven, 239 p.

Verhaegen, J., 2020. Stratigraphic discriminatory potential of heavy mineral analysis for the Neogene sediments of Belgium. Geologica Belgica, 23/3-4, this volume. https://doi.org/10.20341/gb.2020.003

Verhaegen, J., Weltje, G.J. \& Munsterman, D., 2019. Workflow for analysis of compositional data in sedimentary petrology: provenance changes in sedimentary basins from spatio-temporal variation in 
heavy-mineral assemblages. Geological Magazine, 156, 1111-1130. https://doi.org/10.1017/s0016756818000584

Vinken, R., 1988. The Northwest European Tertiary Basin. Geologisches Jahrbuch, Reihe A, 100, 508 p.

Willems, W., Laga, P. \& Moorkens, T., 1988. Benthic foraminifera Belgium. In Vinken, R. (ed.), The Northwest European Tertiary Basin. Geologisches Jahrbuch, Reihe A, 100, 179-188.

Wouters, K. 1978. Een systematische, biostratigrafische en paleobiologische studie van de Ostracoda uit de Miocene afzettingen in Noord-België. Unpublished Ph.D. Thesis, KU Leuven, Leuven, 3 vol.

Wouters L. \& Vandenberghe, N., 1994. Geologie van de Kempen. ONDRAF-NIRAS, Brussel, NIROND-94, $208 \mathrm{p}$.

Zachos, J.C., Pagani, M., Sloan, L., Thomas, E. \& Billups, K., 2001. Trends, rhythms, and aberrations in global climate $65 \mathrm{Ma}$ to present. Science, 292, 686-693. https://doi.org/10.1126/science.1059412

Ziegler, P.A. 1990. Geological Atlas of Western and Central Europe. Shell International Petroleum Maatschappij, The Hague, 239 p. 